Sampling Design 0ptimization and Establishment of Baselines for Herpetofauna Arrays at the Point Loma Ecological Reserve

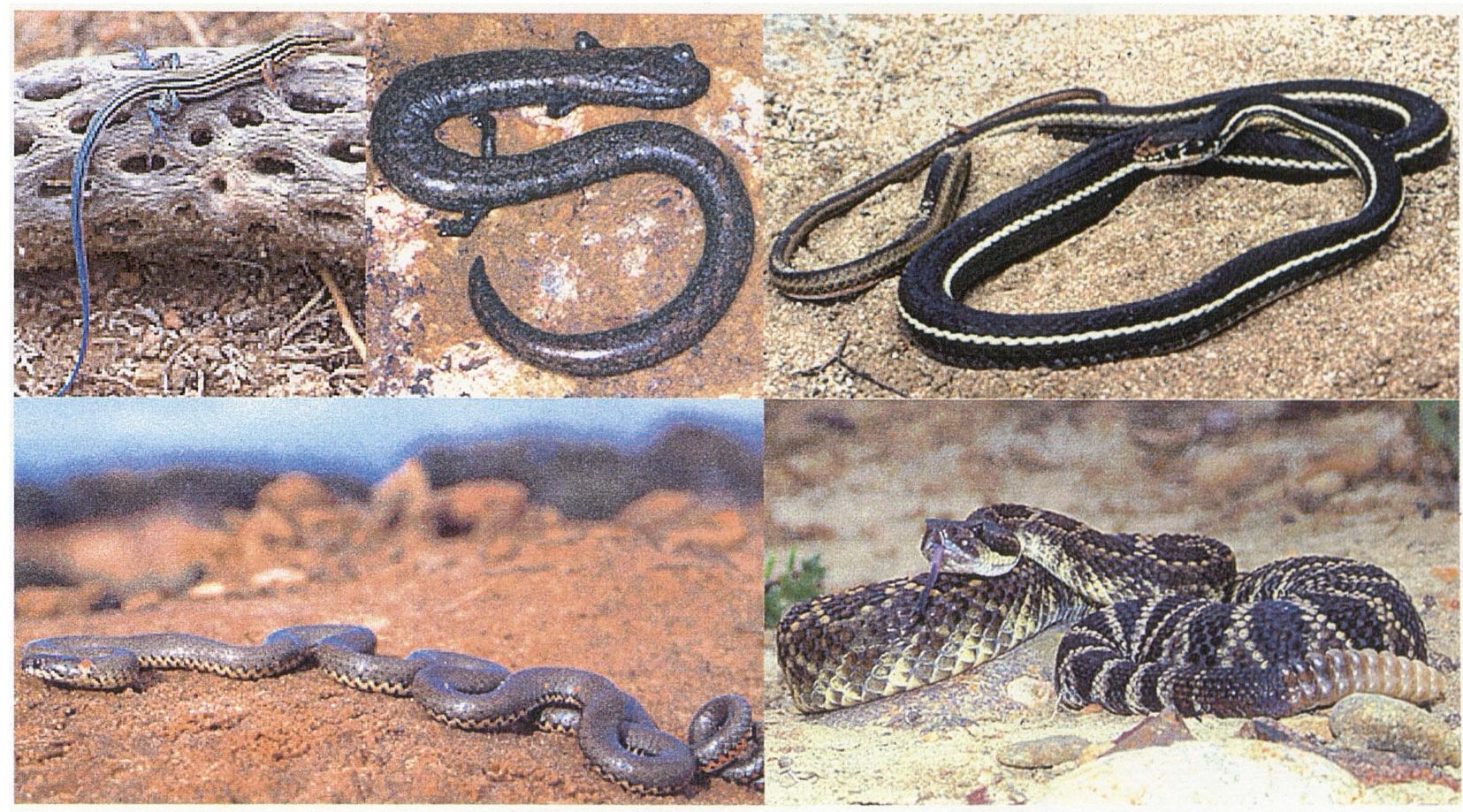

Photos by Chris Brown, U. S. Geological Survey

Prepared for:

National Park Service

Cabrillo National Monument

U.S. DEPARTMENT OF THE INTERIOR

U.S. GEOLOGICAL SURVEY

WESTERN ECOLOGICAL RESEARCH CENTER 



\section{Sampling Design Optimization and Establishment of Baselines for Herpetofauna Arrays at the Point Loma Ecological Reserve}

By Andrea J. Atkinson, Robert N. Fisher, Carlton J. Rochester, and Christopher W. Brown

U.S. GEOLOGICAL SURVEY

WESTERN ECOLOGICAL RESEARCH CENTER

Prepared for:

National Park Service

Cabrillo National Monument

San Diego Field Station

USGS Western Ecological Research Center

5745 Kearny Villa Road, Suite M

San Diego, CA 92123

Sacramento, California

2003 





\section{TABLE OF CONTENTS}

INTRODUCTION ........................................................................... 1

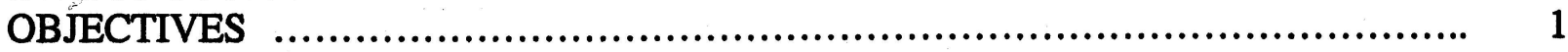

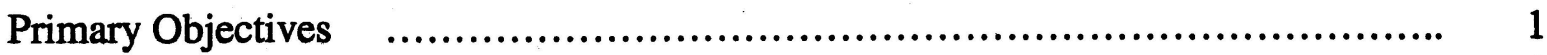

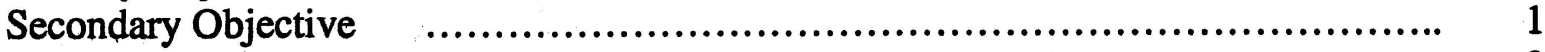

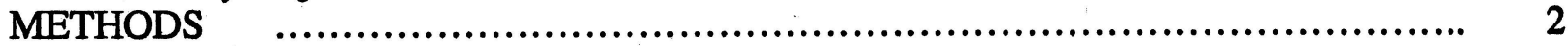

Pitfall trap array protocol and sampling locations ..................................... 2

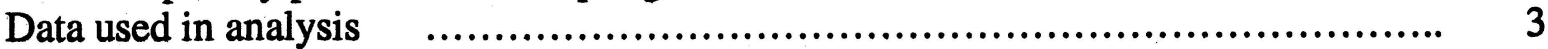

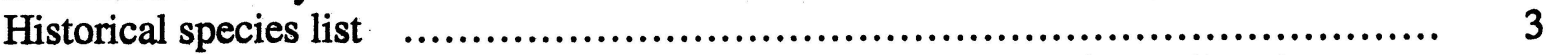

Trend analysis and determination of number of arrays, number of sampling days per year, and timing of sampling periods ..................................................... 4

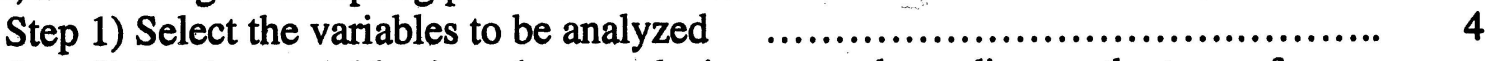

Step 2) Sorting variables into three analysis groups depending on the type of data involved ........................................................................... 5

Step 3) Conduct regression analyses to test for existing trends $\ldots \ldots \ldots \ldots \ldots \ldots \ldots \ldots . . . . .5$

Step 4) Conduct sample size calculations for the number of arrays needed to detect a change assuming different numbers of sampling days per year (i.e., 20, 30,40 , and 50 sampling days per year)

Step 5) Develop preliminary $95 \%$ and $99 \%$ control limits where possible to determine when the capture rate during a new year is outside the range of variation experienced in the baseline years Step 6) Determine optimum number of arrays, number of sampling days per year, and timing of sampling periods by examining the results

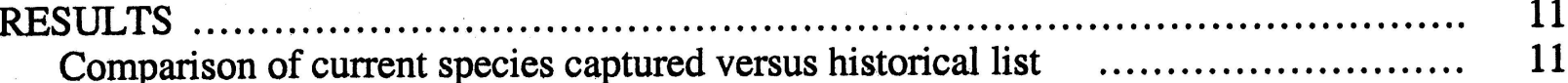

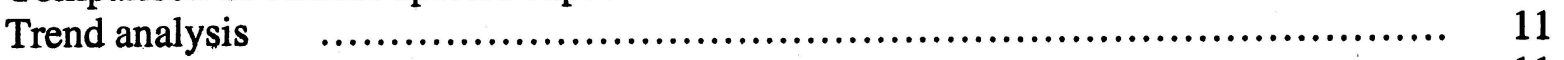

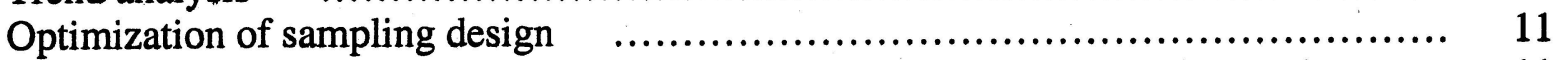

$\begin{array}{lll}\text { Number of species detect per array (used as surrogate for species richness) } & \ldots . . . . & 11\end{array}$

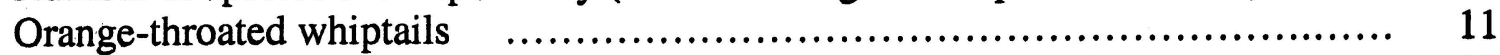

Striped racer, ring-necked snakes, and southern Pacific rattlesnake $\quad \ldots \ldots \ldots \ldots \ldots \ldots . .12$

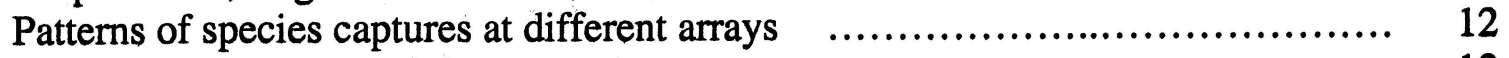

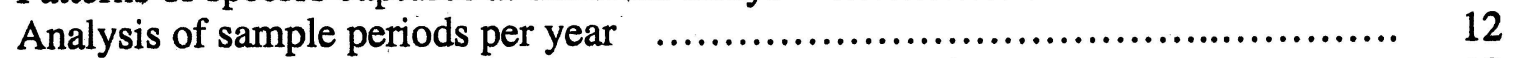

Analysis of associations between species and habitat variables $\quad \ldots \ldots \ldots \ldots \ldots \ldots \ldots \ldots .13$

DISCUSSION F................................................................... 13

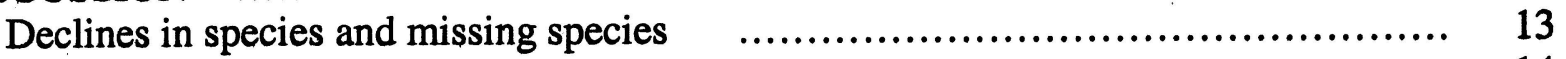

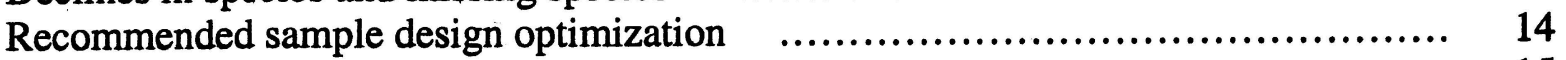

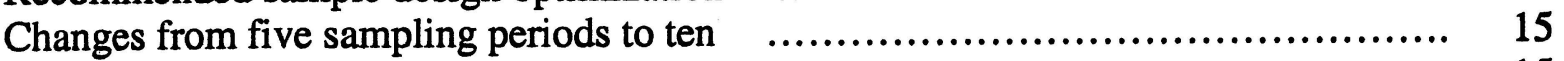

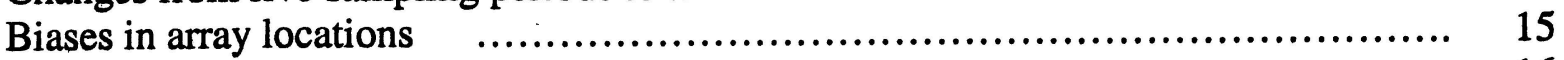

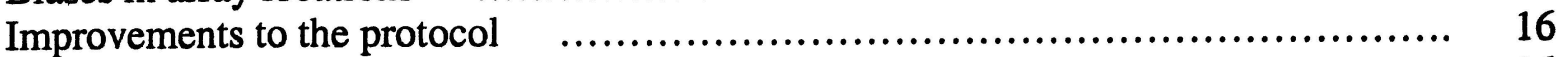

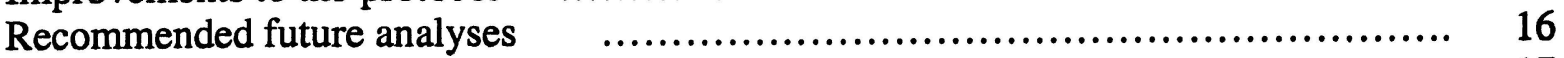

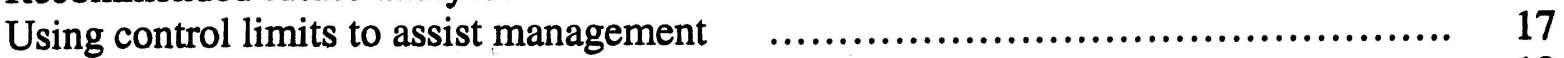

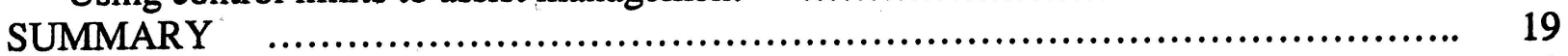

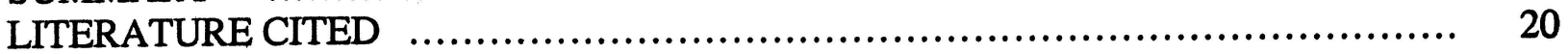





\section{LIST OF TABLES}

Table 1. Start dates for 10-day sampling periods within each year. …................. 3

Table 2. Variables grouped by analysis Groups 1,2, and 3. ............................ 6

Table 3. Total herpetofauna captures per year for years 1996-2000. ................... 22

Table 4. Trend analysis and optimization analysis for average number of species detected, species evenness, total herpetofauna captures, and lizard captures per array per year.

Table 5. Trend analysis and optimization analysis for orange-throated whiptail captures and juvenile orange-throated whiptail captures per array per year

Table 6. Calculation of $95 \%$ and $99 \%$ confidence levels for total number of snake captures per year, striped racer captures per year, and number of arrays occupied by snakes, striped racers only, orange-throated whiptails and juvenile orange-throated whiptails.

Table 7. Calculation of control limits for juvenile striped racers, ring-necked snakes and southern Pacific rattlesnake.

Table 8. Captures during each day in sample period summed across all sampling periods from 1996-2000.

Table 9. Total herpetofauna captures per array for years 1996-2000.

Table 10. Striped racer captures by year and array for adults plus juveniles and juveniles only.

Table 11. Number of captures by sampling period from years 1996-2000.

Table 12. Dependent and independent variables in stepwise regression analysis. ......... 31

Table 13. Environmental variables stepwise regression results. . ........................ 32

Table 14. List of species detected since 1995 versus historical records. $\quad . . . . . . . . . . . . . . .33$

Table 15. Summary table of preliminary control limits for detecting changes from the baseline years 1996-2000.

\section{LIST OF FIGURES}

Figure 1. Map of Point Loma Ecological Reserve herpetofauna arrays

Figure 2. Coefficient of variation (CV) for orange-throated whiptail for arrays with $>2$ captures

Figure 3. Cumulative number of species detected across all 17 arrays at increasing number of sampling days per year

Figure 4. Number of new captures per day by sampling day within the sampling period... 38

Figure 5. Juvenile orange-throated whiptails: Number of captures by year and array ...... 39 



\section{INTRODUCTION}

Cabrillo National Monument is the terminal point of the Point Loma Peninsula and part of the Point Loma Ecological Reserve, which protects the natural lands remaining on the peninsula in urban San Diego, California. This reserve is isolated from other natural lands by the ocean and urbanization, and is an effective island of rare habitats. These habitats include maritime succulent scrub, coastal sage scrub, and chaparral, and are the home to many sensitive species of plants and animals. Historically (through the 1930s), 19 species of reptiles and amphibians occurred on the peninsula, of which 6 are now considered sensitive at the state or federal level. Herpetofauna inventories were initiated by Robert Fisher of the U.S. Geological Survey (USGS) and Ted Case of the University of California at San Diego in August 1995, utilizing 17 arrays of pitfall traps and drift fences (Stokes et al., 2004). Data collection occurred from 1995 through 2001 to collect baseline data for the development of a long-term monitoring plan (Fisher and Case, 2000).

\section{OBJECTIVES}

The National Park Service will be taking over the monitoring arrays for herpetofauna at the Point Loma Ecological Reserve from USGS. The purpose of this analysis is to examine the baseline data set and determine how many arrays, sampling periods, and days per sampling period are needed to assess whether herpetofauna diversity is being maintained on the reserve and suggest points for when management actions should be considered. The specific objectives listed below were identified by the reserve science manager as the ones most important to target. Although financial costs are a consideration in reducing the amount of sampling that is occurring, environmental impact is of greater concern. Erosion due to foot traffic is occurring at some sampling arrays placed on steeper slopes. Thus the benefits of maintaining the current number of sampling days and sampling arrays must be weighed against possible environmental costs. An additional constraint is that although reductions in sampling effort would be considered, increases in the number of arrays are not likely to be funded.

\section{Primary objectives}

1) What species are currently found at Point Loma Ecological Reserve versus species that have been historically found in this area?

2) Are any of the targeted species showing declines at present?

3) How many arrays, sampling periods, and sampling days per sampling period would be needed to detect a

- $30 \%$ drop in species richness,

- $30 \%$ drop in the relative abundance of orange-throated whiptail (Cnemidophorus hyperythrus) and striped racer (Masticophis lateralis),

- some measure of drop in abundance or occupancy of western ring-necked snake (Diadophis punctatus) and southern Pacific rattlesnake (Crotalus viridis).

Secondary objective

4) What relationships are found between targeted species and environmental variables? 


\section{METHODS}

\section{Pitfall trap array protocol and sampling locations}

The draft herpetofauna pitfall trap array protocol, techniques, and design are described in Stokes et al. (2004). To better understand the status and distribution of reptiles and amphibians throughout the Point Loma Ecological Reserve, pitfall trap array sites were chosen to represent the range of habitats found in the peninsula. Point Loma was stratified by vegetation, and the numbers of arrays were placed in each habitat type in approximate proportion to the proportion of that habitat type present, with the additional inclusion of unique landscape features if present (e.g., open sandy washes). The primary components of native vegetation at Point Loma include baccharis, black sage, buckwheat, cacti, chamise, cliffspurge, and manzanita and vary depending on aspect, exposure and slope, substrate, and disturbance.

Several additional considerations affected array site locations including feasibility, access, visibility, habitat sensitivity. Arrays could not be placed on steep slopes or in areas where it was not possible to bury 5-gallon buckets and drift fencing in the ground. Soil type, however, did not limit array location, because the substrates on the peninsula include mostly soils, sand and sandstone deposits. Arrays were placed near roads and trails so that they could be reasonably accessed by surveyors on a daily basis without trampling large amounts of native vegetation. Sensitivity to habitat was considered. Arrays were built with caution to impact native vegetation as little as possible, with arms bent around plants rather than running through them. Visibility of the array to park visitors was another important factor. To minimize visitation to the arrays by park visitors, arrays within the park were placed on slopes facing away from trails and in areas that had sufficient vegetation to hide the array.

Although the locations of arrays within vegetation types were not chosen with strict random procedures, the area of Point Loma is so small and so much of the terrain has steep slopes that arrays were placed in nearly all locations where it was physically feasible to do so and access was allowed. The sampling design contains some admitted biases, since areas with steep slopes are not sampled and areas that are far from roads and trails may be underrepresented. However, given the small size of the park, the effects of these biases are expected to be minimal. Locations of the 17 pitfall trap arrays are shown in Figure 1.

Steps were taken to minimize direct impacts by park visitors on the survey efforts, including careful array placement as previously mentioned. Trails to arrays were often covered with brush to discourage off-trail travel, and information labels were placed on the array equipment. However, the large numbers of visitors and relatively small size of the park resulted in trails and roads being heavily traveled. Arrays \#13-17 are located near a popular trail. Arrays \#13 and \#14 are directly below the Old Lighthouse, which attracts many visitors. Arrays \#1-4 are near the tide pools, another area with high traffic. Although not documented, it is likely that visitation rates to these arrays are much greater than to arrays \#5-12, which require security clearance to be accessed.

The sampling protocol may have some inherent biases towards capturing fauna that are very active and mobile and travel on the surface of the ground, rather than those that move infrequently or travel beneath the soil surface. The traps are passive, not baited. For animals to be captured by the traps, the animals must be active enough to encounter and enter the traps. In general, animals that move around more actively through an area may be more likely to 
encounter the traps. For example, the striped racer, an active forager, may move around in an area more than a southern Pacific rattlesnake, generally a sit-and-wait predator. Live traps similar to the funnel traps used in this survey are documented to work better with medium-sized snakes. Larger-bodied snakes including gopher snakes and rattlesnakes are more commonly detected by visual observation than captured (Fitch, 1992). Furthermore, the trap openings are above ground or on the immediate surface. Animals that spend larger amounts of time underground, such as the silvery legless lizard (Anniella pulchra), may encounter the trap openings less frequently than other species.

\section{Data used in analysis}

Analyses were conducted on data collected from the 17 existing herpetofauna arrays at the reserve during the years 1996-2000. Each year consisted of 5 sampling periods (see Table 1). Although data are available for years 1995 and 2001, these data did not consist of a complete set of sampling periods at the time of analysis and thus are not included in this analysis.

Table 1. Start dates for 10-day sampling periods within each year.

\begin{tabular}{|c|c|c|c|c|c|}
\hline & \multicolumn{5}{|c|}{ Year } \\
\hline Period within year & 1996 & 1997 & 1998 & 1999 & 2000 \\
\hline 1 & $2 / 20$ & $2 / 18$ & $2 / 3$ & $1 / 27$ & $2 / 9$ \\
\hline 2 & $4 / 23$ & $4 / 22$ & $3 / 31$ & $4 / 6$ & $4 / 5$ \\
\hline 3 & $6 / 25$ & $6 / 24$ & $6 / 2$ & $6 / 8$ & $6 / 6$ \\
\hline 4 & $8 / 27$ & $9 / 3$ & $8 / 4$ & $8 / 18$ & $8 / 29$ \\
\hline 5 & $10 / 29$ & $10 / 28$ & $10 / 6$ & $11 / 10$ & $11 / 10$ \\
\hline
\end{tabular}

Data from all 5 sampling periods within each year were combined into a total capture rate per array per year for analysis. Although sampling dates were not exactly the same in all years, they were roughly comparable. Animals recaptured at the same array within the same 10-day sampling period were only counted once.

It should be noted that 1998 was considered an $\mathrm{El}$ Niño year, with associated increases in rainfall. The years 1996, 1999, and 2000 were considered drought years with very low rainfall.

Historical species list

A historical list of species present or presumed present at Point Loma was compiled by examining species records at the San Diego Natural History Museum, California Academy of Sciences, Los Angeles County Museum, University of California at Berkeley Museum of Vertebrate Zoology, and the field notes and species maps of Laurence M. Klauber (unpublished notes from San Diego Natural History Museum). 
Trend analysis and determination of number of arrays, number of sampling days per year, and timing of sampling periods

The overall process to optimize the sampling design was in fact multi-dimensional. The level of sampling effort could be affected in three ways:

- number of arrays

- number of sampling days per year

- timing of sampling throughout the year (i.e., number and timing of sampling periods and days per sample period)

Additional factors that affected the final result were the species and variables of interest plus the acceptable level of Type I error $(\alpha)$ and Type II error ( $\beta=1$-Power) (described further below).

The process used to optimize the sampling design and identify potential management thresholds was broken into six steps. These included:

1) Select the variables to be analyzed.

2) Sort variables into three analysis groups, depending on the type of data involved.

3) Conduct regression analyses to test for existing trends.

4) Conduct sample size calculations for the number of arrays needed to detect a change, assuming different numbers of sampling days per year (i.e., 20, 30, 40, and 50 sampling days per year).

5) Develop preliminary $95 \%$ and $99 \%$ control limits, where possible, to determine when the capture rate during a new year is outside the range of variation experienced in the baseline years.

6) Determine optimum number of arrays, number of sampling days per year, and timing of sampling periods by examining the results.

\section{Step 1) Select the variables to be analyzed.}

The variables analyzed include

- Number of species detected per array (used as surrogate for species richness)

- Simpson's measure of species evenness ${ }^{1}$

- Herpetofauna captures (lizards, snakes, and salamanders)

- Lizard captures

- Snake

- captures or sightings

- \# arrays with 1 or more snake captures

- Orange-throated whiptail (Cnemidophorus hyperythrus)

- Total captures

- Juveniles captures

- \# arrays with 1 or more captures

- \# arrays with 1 or more juvenile captures

\footnotetext{
'Simpson's evenness is a measure that evaluates the degree to which all species present are equally common (i.e., is the community dominated by a few species and all other species put in rare occurrences, or are all species present equally common). Simpson's evenness is calculated as $E=\left(1 / \Sigma_{1}^{3}\left(p_{i}\right)\right) / s$ where $s=\#$ species in the sample and $P_{1}=$ proportion of total sample belonging to the ith species (Krebs, 1999)
} 
- Striped racer (Masticophis lateralis)

- captures or sightings

- juvenile captures or sightings

- \# arrays with 1 or more striped racer captures

- Ring-necked snake (Diadophis punctatus) captures or sightings

- Southern Pacific rattlesnake (Crotalus viridis) captures or sightings

Step 2) Sorting variables into three analysis groups depending on the type of data involved. Variables were separated into three different "analysis groups" depending on the number of captures that occurred and the distributions of the variables (see Table 2).

Group 1 - Variables in this group had large amounts of data at all or nearly all arrays. It was possible to analyze these data using averages per array per year, and these were the variables used to conduct sample size calculations. Analyses for this group included a) a regression analysis in which arrays were treated as class variables and years were treated as a regression variable, b) sample size calculations, and c) calculation of control limits.

Group 2 - This group involved species such as striped racer which had much smaller numbers of captures than Group 1 species, even when captures were summed across all arrays ( 15 or less captures per year). This group of variables consists of either i) total number of captures summed across all arrays or ii) the number of arrays at which an organism was present. Analyses for this group included: a) a regression analysis and b) calculation of control limits.

Group 3 - This group involves species with very low capture rates summed across all arrays per year (i.e., 3 or less captures per year). Analysis included calculation of the control limits for the expected number of years with zero captures.

Since variance strongly increased with number of captures, a square root transformation was used on most variables in Group 1 with the exception of species evenness.

Sample size analyses on orange-throated whiptail were performed on all arrays and then a subset of arrays \#1-4, 9-10, and 13-17. Arrays \#5-8 and 11-12 were dropped from the analysis, since they had fewer than 2 captures across all 5 years and this artificially inflated the variance and coefficient of variation (CV) during sample size calculations.

Although separate analyses were not conducted on all species, the number of captures per year for all species are included in Table 3.

Step 3) Conduct regression analyses to test for existing trends. A regression analysis was performed on variables in Groups 1 and 2 to test for trends occurring in the existing data sets. This was both of interest biologically and as a necessary prerequisite for calculating control limits in the next section. Results are given in Tables 4 and 5. 
Table 2. Variables grouped by analysis Groups 1, 2, and 3. Group 1 was analyzed by year and array. Direct sample size calculations were performed on this group. Group 2 variables were summed across arrays and were analyzed as total captures per year or number of arrays with organism present. Group 3 consisted of small numbers of captures (i.e., 3 or fewer captures per year) and were analyzed using Poisson probability calculations.

a

\begin{tabular}{|c|c|c|c|c|}
\hline \multicolumn{2}{|c|}{ Analysis Group } & \multirow{2}{*}{\begin{tabular}{|l|} 
Variable name \\
Number of species detected \\
\end{tabular}} & \multirow{2}{*}{$\begin{array}{l}\text { Specific variables } \\
\text { \# species detected / array / year }\end{array}$} & \multirow{2}{*}{$\begin{array}{l}\text { Data } \\
\text { transformation } \\
\text { Square root }\end{array}$} \\
\hline \multirow{7}{*}{1} & \multirow{7}{*}{$\begin{array}{l}\text { Analysis performed by array } \\
\text { and year; } \\
\text { - Sample size calculations; } \\
\text { - Regression analysis; } \\
\text { - Control limits }\end{array}$} & & & \\
\hline & & Simpson's evenness & Evenness / array / year & \\
\hline & & Herpetofauna capture rates & Captures / array/year & Square root \\
\hline & & Lizard capture rates & Captures / array/ year & Square root \\
\hline & & \multirow{3}{*}{ Orange-throated whiptails capture rates } & $\begin{array}{l}\text { Captures / array / year } \\
\text { (all arrays included) }\end{array}$ & Square root \\
\hline & & & $\begin{array}{l}\text { Captures / array / year } \\
\text { (arrays 1-4,9-10,13-17) }\end{array}$ & Square root \\
\hline & & & $\begin{array}{l}\text { Juvenile captures/array/year } \\
\text { (arrays } 1-4,9-10,13-17 \text { ) }\end{array}$ & Square root \\
\hline \multirow{6}{*}{2} & \multirow{6}{*}{$\begin{array}{l}\text { Analysis performed on totals } \\
\text { or percentages across all } \\
\text { arrays by year; } \\
\text { - Regression analysis; } \\
\text { - Control limits }\end{array}$} & \multirow{2}{*}{ Orange-throated whiptails } & \# arrays with whiptails present & \\
\hline & & & \# arrays with juveniles present & \\
\hline & & \multirow{2}{*}{ Snake capture rates } & Captures / year & \\
\hline & & & \# arrays with snakes present & \\
\hline & & \multirow{2}{*}{ Striped racer capture rates } & Captures / year & \\
\hline & & & \# arrays with racers present & \\
\hline \multirow{3}{*}{3} & \multirow{3}{*}{$\begin{array}{l}\text { Analysis performed on totals } \\
\text { across all arrays by year; } \\
\text { - Estimated probabilities of } \\
\text { consecutive years with } \\
\text { zero captures }\end{array}$} & Striped racers - juvenile capture rates & Captures/year & \\
\hline & & \begin{tabular}{|l|} 
Ring-necked snakes \\
\end{tabular} & Captures / year & \\
\hline & & Southern pacific rattlesnake & Captures / year & \\
\hline
\end{tabular}


Step 4) Conduct sample size calculations for the number of arrays needed to detect a change assuming different numbers of sampling days per vear (i.e. 20,30,40, and 50 sampling days per yearl.

Sample size calculations (i.e., number of arrays) were done directly for variables in Group 1 and indirectly for Groups 2 and 3 . For Group 2, confidence intervals were calculated to determine if there was any power to detect change. If the lower confidence limit is a 1 or 0 , then the number of arrays was considered too small to detect any change whatsoever. Group 3 calculations were also very indirect. In Group 3, the probabilities for increasing numbers of years with zero captures were calculated. If this number of years with zero captures seemed exceedingly high, then a higher level of effort would be needed to realistically track the species. Thus, although an assessment of the power to detect differences could be made for Group 1, no assessment of power could be made for Groups 2 and 3 variables.

To detect a change in the future, the recommended method of analysis for Group 1 variables is to a) conduct an analysis of variance and perform a contrast analysis that compares any future year's data with the baseline set of 5 years, and b) conduct a regression analysis.

To calculate the recommended sample size, an analysis of variance was performed in which both years and arrays were included as class variables (i.e., each year was treated as a separate class rather than as a single regression variable). The error variance (i.e., the mean square error or MSE), from this analysis is used to estimate sample sizes. The following equation:

$$
n \geq 2(s / d)^{2} *\left(Z_{\alpha / 2}+Z_{\beta}\right)^{2} \quad(\text { Steel and Torrie, 1980) } \quad \text { Eqn } 1.1
$$

was converted into a more easily used format by dividing both $s$ and $d$ by the mean $\bar{x}$ for ease of calculation. $Z$ values were replaced by t-values as recommended by Geng and Hills (1989) when dealing with potentially small sample sizes.

$$
n \geq 2(C V / D)^{2} *\left(t_{\alpha / 2, d f}+t_{\beta, d f}\right)^{2} \quad \text { (Geng and Hills, 1989) } \quad \text { Eqn } 1.2
$$

where $\bar{x}=$ sample mean of all 5 years

$s^{2}=$ mean square error (MSE) from the analysis of variance

$d=$ difference from the mean

$\mathrm{CV}=\mathrm{s} / \bar{x}=$ Coefficient of Variation

$\mathrm{D}=d / \bar{x}=$ proportional difference from mean (i.e., a 30\% drop in the mean)

$n=$ number of arrays

$\mathrm{df}=$ degrees of freedom

$\alpha=$ probability of a Type I error

$\beta=$ probability of a Type II error, (Note: Power $=1-\beta)$

Note: A Type I error is the conclusion that a capture rate in a new year is different from the baseline when in fact it is not. A Type II error is the conclusion that a capture rate in a new year is not different from the baseline years when in fact it is different. 
Sample size calculations were conducted assuming $\alpha=0.05$ and $\beta=0.10,0.20$, and 0.30 (i.e., power levels of $1-\beta$ or $90 \%, 80 \%$, and $70 \%$, respectively).

Four different data sets were created by taking subsets of the complete data set of the first 10 days, 8 days, 6 days, or 4 days of each of the five sampling periods per year, resulting in data sets of $50,40,30$, or 20 sampling days per year. Separate sample size calculations were conducted on each data set on each Group 1 variable. These results are shown in Tables 4 and 5.

Based upon the results, orange-throated whiptail capture rates appeared to be a driving factor in determining sample size. Figure 2 shows how the Coefficient of Variation for orange-throated whiptail captures varies in response to number of sampling days per year.

Step 5) Develop preliminary $95 \%$ and $99 \%$ control limits where possible to determine when the capture rate during a new year is outside the range of variation experienced in the baseline vears.

Control limits is a technique used in quality control in industries to monitor whether a process such as the number of defective units (e.g., toys with defective packaging) is remaining in "control" (i.e., within acceptable limits) without having to continually re-run statistical analyses. We are adapting these methods to allow easier analysis by reserve managers for Group 2 variables (McBean and Rovers, 1998; Manly, 2001; Montgomery, 2001). Analysis of Group 1 variables should preferably use an analysis of variance coupled with a contrast analysis to achieve greater sensitivity. However, if a year falls outside the control limits for Group 1 variables, it will also be found to be significantly different with the analysis of variance. Thus, the control limits can be used as a coarse guide for Group 1 variables, in addition to Groups 2 and 3.

Frequently, these control limits are calculated from $95 \%$ and $99 \%$ confidence limits. Calculation of these confidence limits varies, depending on whether the data are normally distributed or are Poisson distributed.

\section{Normal distribution}

$$
\text { Confidence Limits }=\bar{x} \pm Z_{\alpha_{12}} S \quad \text { (based on Montgomery, 1998) Eqn } 1.3
$$

\section{Poisson distribution}

$$
\begin{array}{llll}
\text { Lower limit }=\chi_{(1-\alpha / 2, v)}^{2} / 2 & \text { where } v=2 * \bar{x} & \\
\text { Upper limit }=\chi_{\left(\alpha_{1 / 2}, v\right)}^{2} / 2 & \text { where } v=2 *(\bar{x}+1) & (\text { Zar, 1999) } & \text { Eqn } 1.4
\end{array}
$$

Since only five years of data were used to create these control limits, they should be considered "preliminary" control limits.

It's important to note that the calculation of these control limits and number of years of zero captures is dependent on the assumption that no trend was occurring during the baseline 5 years. If a trend was occurring during this time period, then these limits are not valid. Any data transformations that were performed prior to calculation of these limits must also be performed on data collected in the future before comparing with these limits. 


\section{Group 1 control limits}

All the control limits for Group 1 variables were calculated using equation 1.3 and are based upon the average capture rate per array per year for each of the five years.

If a new year's average per array falls outside the control limits, then that year's data are considered significantly different from the baseline years. Please note that such averages must be calculated from appropriately transformed data as mentioned in the tables. Control limits are given in Tables 4 and 5.

\section{Group 2 control limits}

For Group 2 variables, the control limits given in this report, coupled with regression analyses will be the primary ways of determining whether a new year of data collection is considered significantly different from the baseline 5 years. Since these data consist primarily of small numbers in which the variance is approximately equal to the mean, the Poisson control limits were most appropriate (i.e., Equation 1.4). The exception was number of arrays with orangethroated whiptail present which had such a small variance that the normal distribution calculation was more appropriate, (i.e., Equation 1.3). Control limits are given in Table 6.

Group 3 control limits: Number of years with zero captures

Group 3 consisted of species with only 8 captures or less summed across all 5 years or 3 or fewer captures in any single year (i.e., southern Pacific rattlesnake, ring-necked snake, and juvenile striped racers; see Table 7). Even snakes observed while walking to and from the arrays were included under the assumption that the amount of effort was roughly equivalent across years. Analysis for this group consisted of calculating the probability of multiple years with zero captures based upon a Poisson distribution. If the number of years with zero captures at the 5\% probability level was unrealistically high, then a larger sample size would be recommended.

$$
\begin{aligned}
& \text { Probability of zero captures per array }=P(0)=e^{-\mu} \text { (Steel and Torrie, 1980) Eqn } 1.5 \\
& \text { Probability of multiple zero captures }=\left(e^{-\mu}\right)^{n \cdot y} \\
& \mu=\text { true population average number of captures per array per year assuming an infinite } \\
& \text { number of years (this analysis substituted } \bar{x} \text {, the average across all arrays and } 5 \text { years, } \\
& \text { for } \mu \text { ) } \\
& \mathrm{n}=\text { number of arrays } \\
& y=\text { number of years }
\end{aligned}
$$

Control limits were calculated based on when the probability for a given number of consecutive years of zero captures fell below 5\%. One capture was added and subtracted from the calculations to determine how robust the limit was, and if the number of years calculated changed, the control limits were expanded accordingly. The control limit range given represents the number of years with zero captures whose expected probability is below 5\% (see Table 7). These control limits should be used with extreme caution and wisdom, since they were calculated based on an exceedingly small samples. 
Step 6) Determine optimum number of arrays, number of sampling days per year, and timing of sampling periods by examining the results.

The following factors were taken into consideration in optimizing the sampling design:

- Optimal design needed to assess trends in number of species detected per array, orangethroated whiptails, striped racers, ring-necked snakes, and southern Pacific rattlesnakes. To start determining the optimum number of arrays and number of sampling days per year required looking at the results of all the response variables and determining which would require the highest number of arrays to detect a desired level of change (see Tables $4,5,6$, and 7 ). In addition, species that appeared to be experiencing declines during baseline years were flagged, because the sampling design would need to continue tracking these species effectively (e.g., striped racer). Other factors, such as the time required to detect rarer species under differing numbers of sampling days per year (see Figure 3 ) and the decline in the capture rate late in the sampling period compared with early in the sampling period, were also taken into account (see Figure 4 and Table 8).

- Species captured at each array. Not all species were captured consistently at all arrays. The number of captures of each species at each array is shown in Table 9, and in greater detail for striped racer in Table 10. Since the number of arrays was so small, rather than randomly selecting arrays to eliminate, arrays were identified that were consistently yielding low captures of targeted species and expected to continue doing so in the future.

- Capture rates during different sampling periods. The number and timing of sampling periods per year were examined qualitatively after the other sample size calculations were conducted (see Table 11) to determine if some sampling periods could be eliminated without effecting results.

All of these factors were taken into consideration for making final recommendations to optimize the sampling design.

\section{Analysis of associations between species and habitat variables}

A stepwise forward/backward regression analysis was conducted to determine the variables most strongly correlated with the distribution of various species and categories of fauna. The variables used are shown in Table 12 and are defined more completely in Fisher et al. (2002) and Case and Fisher (2001). The data set was expanded to include all data collected for 1995-2001.

For "number of lizards and salamanders" and "number of orange-throated whiptails," the analysis was run first with environmental variables only, and then a second time with the Argentine ant density category included.

For the "number of snake captures" and "number of striped racer captures only," the analysis was run including environmental variables plus the number of small mammals captured, the number lizards and salamanders captured, and Argentine ant density category as possible independent variables.

For the Argentine ant density category, only environmental variables were included in the model. Results are shown in Table 13. 


\section{RESULTS}

\section{Comparison of current species captured versus historical list}

Table 14 contains a list of species currently found during sampling at Point Loma versus those found historically. Only 12 of the original 19 species were detected between 1995 and 2001 after 294 sampling days and 1696 herpetofauna observations. Night Snake (Hypsiglena torquata) was not known from museum records but was added to the historical species list when a single individual was found in 1997. This is a very cryptic species which is difficult to detect and could easily have been missed during earlier surveys, and thus is considered to have historically occurred in this area. Further targeted surveys found only one more individual in 2001 (Yang and Fisher, 2003). Both detections occurred outside the 1996-2000 sampling years used in this analysis. Two occurrences of coastal rosy boa (Charina trivirgata) were found along a roadside and are thought to have been released pets (and probably the same released pet), since this species has not been historically found on the peninsula and is easily detected (Brown and Fisher, 2002). A radio-tracking study included this individual and found it had the largest home range of any of the rosy boas tracked (Rochester et al, 2001), another indication that this was probably an introduced animal. Neither the night snake or the coastal rosy boa were included in this analysis.

\section{Trend analysis}

Number of species detected per array $(p=0.0370)$, captures per year of striped racer $(p=0.0079)$ and number of arrays with striped racer present $(\mathrm{p}=0.0418)$ all had negative trends during the years of 1996-2000 (see Tables 3, 4 and 5). The pattern exhibited by the number of species detected per year suggests that this negative trend could be an artifact of 1998 being a strong El Niño year and 2000 being a drought year (see Table 3 ). In the case of striped racer, however, this decline was very marked with 12 individuals being found in 1996 and only 4 being found in 2000 (see Tables 6 and 9).

\section{Optimization of Sampling Design}

Number of species detected per array (used as surrogate for species richness)

Only 5 arrays sampled 50 days per year or 8 arrays sampled 20 days per year would be needed to detect a decline of $30 \%$ with a power of $80 \%$ (see Table 4 ).

However, decreases in the number of sampling days per year can increase the amount of time needed to detect rare species (see Figure 3).

Orange-throated whiptails

Given the high level of variance in orange-throated whiptail capture rates compared with the mean ( $C V=44 \%$ with all arrays or $32 \%$ with only arrays with $>2$ captures), detection of a decline of $30 \%$, as originally requested by the reserve science manager, would require increasing the number of arrays (see Tables 4 and 5). However, a decline of $40 \%$ could be detected with $80 \%$ power with the 11 arrays that currently capture high numbers of whiptails (i.e., arrays \#1-4, 9-10, 13-17). If the number of sampling days per year were reduced from 50 to 40 sampling days, these 11 arrays could detect a decline of approximately $45 \%$ with $80 \%$ power. Any further decrease in sampling effort will result in increases in the CV and will require increasing the number of arrays (see Figure 2). 
Juvenile orange-throated whiptails have a very high level of variance from array to array and from year to year (see Figure 5). The 11 arrays with high orange-throated whiptail captures will only detect a $65 \%$ decline with $80 \%$ power even when sampled 50 days per year. At 40 sampling days per year, those 11 arrays will detect a $75 \%$ decline with $80 \%$ power.

Thus, to detect changes in orange-throated whiptail capture rates, the 11 arrays which have high capture rates should be maintained (i.e., arrays \#1-4, 9-10, 13-17). The number of sampling days per year should be kept to 40-50 days per year.

\section{Striped racer, ring-necked snakes, and southern Pacific rattlesnake}

Given the small number of captures of striped racer, ring-necked snake, and southern Pacific rattlesnake, only a small reduction in sampling effort, if any, would be advised to maintain an ability to detect changes in these species, especially since there is a concern that striped racer abundance may be declining (see Tables 6, 7, and 10). Any arrays that are eliminated should not include arrays with large numbers of captures of any of these snake species (see Table 9).

\section{Patterns of species captures at different arrays}

The ability to detect changes in capture rates for orange-throated whiptail, striped racer, ringnecked snake, and southern Pacific rattlesnake appears to be driving the sampling design optimization.

The only array that showed no captures of any snakes or orange-throated whiptails is array \#6 (see Table 9). Arrays \#2 and 16 had no striped racer captures but did have high capture rates of orange-throated whiptails. Array \#12 had only one capture of orange-throated whiptail and only one capture of striped racer in 1996. Arrays \#5, 7, 8, and 11 all had 3-4 captures of striped racer and ring-necked snakes and thus should be maintained, if the ability to detect changes in these snake species is desired.

\section{Analysis of sample periods per year}

Based upon captures for striped racer and maintaining an ability to detect all species, sampling should continue during all 5 sample periods. The number of species captured by sampling period is included in Table 11. Based upon the sampling design optimization analysis, capture rates for orange-throated whiptail, striped racer snake, ring-necked snake, and southern Pacific rattlesnake drove the determination of the number of arrays necessary. Thus, any reduction or alternation in number of sample periods per year must not impact these four species. None of these species was captured in large numbers in the Jan/Feb sampling period (period 1). Eliminating period 1 would have little impact on analysis of orange-throated whiptail but would possibly affect capture rates of striped racer. In addition, Jan/Feb is the primary period when the garden slender salamander is collected. If tracking at least the continued presence of the garden slender salamander is important, then some sampling needs to be maintained in this period.

Note: Although the only detection of the silvery legless lizard occurred during the Jan/Feb sampling period in this data set, it was also captured once each in 1995 and 2001 during summer, so its detection is not limited to winter months. 


\section{Analysis of associations between species and habitat variables}

The results of the stepwise regression are given in Table 13. Only a few highlights are mentioned here, as a more comprehensive analysis is planned for 2004 using data from multiple sites. In general, snakes were positively associated with percent cover but negatively associated with canopy height. However, striped racer capture rates were most tightly correlated with the number of small mammals, lizards, and salamanders captured at the same array. Argentine ants were positively associated with percent grass cover and negatively associated with percent coastal sage scrub cover. When the density category of introduced Argentine ants $(1,2$ or 3$)$ was added to the analysis, this variable replaced one or more environmental variables in the regression equations for number of lizards and salamanders, and for number of orange-throated whiptails. Thus, larger densities of Argentine ants were negatively associated with lizard and orange-throated whiptail capture rates.

\section{DISCUSSION}

\section{Declines in species and missing species}

Only 12 of the 19 historical species were detected during the pitfall trap array sampling during 1995-2001 and only 11 during the period of 1996-2000 used in the sample size analysis (see Table 14). A single night snake (Hypsiglena torquata) was found in a bucket in array \#10 in 2001. Species that were not detected include Coronado skink (Eumeces skiltonianus), coast horned lizard (Phrynosoma coronatum), California glossy snake (Arizona elegans), yellowbellied racer (Coluber constrictor), red diamond rattlesnake (Crotalus exsul ruber), coachwhip/red racer (Masticophis flagellum), and long-nose snake (Rhinocheilus lecontei). All of these species have been detected using pitfall trap arrays or walking to and from these arrays at other sites in southern California, although the number of red diamond rattlesnakes, long-nose snakes, California glossy snakes, and night snakes generally tended to be detected in low numbers (Fisher and Case, 2000b). Thus the failure to detect these species at the Point Loma Ecological Reserve is a concern and suggests that $36 \%$ of the herpetofauna species that were historically detectable are either missing or present in very low numbers below thresholds detectable by this large sampling effort (i.e., 294 sampling days across 17 arrays).

The sharp downward trend ( $\mathrm{p}=0.0079)$ in striped racer (Masticophis lateralis) captures from 1996-2000 is a concern. Three different hypotheses have been put forward: 1) the species is in decline at Point Loma Ecological Reserve, 2) the snakes are learning to avoid the traps, 3) the decline is an artifact of 1998, an El Niño year, preceding 2000, a drought year, thereby creating a downward trend in captures that is a response to annual rainfall variation rather than a larger trend, or some combination thereof.

Table 10 shows the pattern of striped racer captures by array and the pattern of juvenile captures. The pattern does not immediately suggest that learning by snakes is occurring. However, a larger scale analysis of Robert Fisher's data of herpetofauna captured from pitfall trap arrays throughout San Diego County will occur in 2004 and the data can be examined to see if other sites show similar immediate declines in striped racers after initiation of sampling. Another way of separating these hypotheses is to pay particular attention to juvenile striped racers and see if they are experiencing a decline, since juveniles would not have experience with the traps. Regardless, the capture rates of striped racers should be closely watched in the near future to see if this apparent decline continues. 
The slight negative trend in the number of species detected per array $(p=0.0370)$ and marginal trend in number of arrays with orange-throated whiptail present $(p=0.0805)$ should be watched but may be an artifact of the $1998 \mathrm{El}$ Niño year preceding the 2000 drought year (see Tables 4 and 5).

The stepwise regression analysis showed that Argentine ant density category was negatively associated with capture rates of lizards and salamanders in total $(p=0.0004)$ and for orangethroated whiptail in particular $(\mathrm{p}=0.0008)$. This result is similar to the findings that Argentine ants have negative impacts on shrews (Laakkonen et al., 2001) and coastal horned lizard (Fisher et al., 2002) and are frequently associated with urban edges. Management of Argentine ants to prevent establishment and expansion throughout the reserve is thus assumed to be important for maintaining native herpetofauna species diversity.

Brown and Fisher (2002) recommended management strategies to try and prevent further declines in herpetofauna species at the Point Loma Ecological Reserve.

Recommended sample design optimization

The ability to detect changes in orange-throated whiptails and in snake species such as striped racer, ring-necked snake, and southern Pacific rattlesnake were what most strongly influenced recommendations regarding sampling design. In short, the recommendations are:

- Reduce the number of sampling days per year from 50 to 40 .

- Eliminate arrays \#6 and 12

Maintaining all 11 arrays at which orange-throated whiptails are currently captured in large numbers is recommended, as this will allow detection of trends in orange-throated whiptail captures of $40 \%-50 \%$ with a power of $80 \%(1-\beta)$. Specifically these are arrays \#1-4, 9, 10, 1317 (see Table 9). The variables of number of species detected per array and total herpetofauna capture rates required even fewer numbers of arrays to detect trends (see Tables 4 and 5). However, so few snake captures were occurring (63 across all 5 years), that only small changes in the sampling design would be advisable to maintain an ability to detect trends in snakes, especially since there is concern that striped racer may be showing a decline. Only arrays with little to no snake captures should be considered for elimination. And the number of sampling days per year should not be reduced below 40 unless the ability to detect snakes can somehow be improved.

Looking at the pattern of species captured across arrays, only arrays \# 6 and 12 should be considered for elimination at this time. Neither of these arrays captured orange-throated whiptails or snakes in large numbers and both are spatially redundant with nearby arrays. Captures at array \#6 had the lowest species detected of all the arrays, and array \#12 had the lowest overall capture rate of all the arrays. Array \#6 is placed closely in between arrays \#5 and \#7 but features fewer habitat elements than the other two arrays. While all three arrays are located in the same sandy wash habitat, arrays \#5 and 7 have arms located in chaparral elements that are not immediately proximate to array \#6. While array \#6 may be useful in determining movements across an open wash from arrays \#5 or 7 if recapture rates are high enough, the wash is a sensitive area, containing a population of the protected Orcutt's Spineflower (Chorizanthe orcuttiana). Removing array \#6 will have little effect on detecting trends in the targeted 
herpetofauna species and may lessen the likelihood of any unintended impacts on the system. Array \#12 has the lowest number of herpetofauna captures of any of the arrays and is located near arrays \#10 and \#11 and so is somewhat redundant in spatial coverage. Only 1 striped racer capture occurred at array \#12 and none at array \#6 and elimination of these arrays shouldn't affect the control limits for this species. No other snake species were captured at these arrays. Arrays \#5, 7, 8, and 11 all had one or fewer captures of orange-throated whiptails. However they all had at least 3 snake captures and should therefore be maintained at present.

The pattern of species captures changes depending on the season. The garden slender salamander (Batrachoseps major) was primarily captured during January-February with no captures in JuneSeptember. However less than $2 \%$ of the orange-throated whiptail captures occurred in JanuaryFebruary and only $5 \%$ of the snake captures occurred in this time period. It might be possible to reduce the sampling in this time period from 10 days to 4 days rather than from 10 days to 8 days as in the other sample periods, unless the ability to detect trends in the salamander is a concern. To optimize detection of salamanders, sampling during this time period should occur after rain events.

If these recommendations are implemented this should result in a 30-35\% reduction in effort. If a further reduction in effort is necessary due to budget limitations, it would be better to sample the 15 arrays every other year than to further reduce the number of arrays to enable sampling every year.

\section{Changes from five sampling periods to ten}

Once the decision was made to reduce the number of sampling days per year from 50 to 40 days, divided as five 8-day sample periods that would occur at approximately the same time of year as the original five 10-day sample periods used in 1996-2000, the question was raised as to whether this could be divided into ten 4-day sample periods instead. From a management point of view, 4-day sample periods are easier to schedule since they can be completed in a single week and don't require surveyors to work weekends or overtime.

While technically it is preferable to follow the protocol used during the baseline years as closely as possible, using ten 4-day sample periods instead of five 8-day sample periods will probably have little effect on the results. The five sample periods during the baseline years varied in their start date by about a month anyway. So shifting to ten 4-day sample periods sampled approximately a month apart is still roughly comparable to five 8-day sample periods sampled about two months apart.

\section{Biases in array locations}

Array location selection was limited because arrays could only be placed in areas that did not have steep slopes and were accessible to surveyors while being out of sight from park visitors. Thus areas that had steep slopes or were otherwise inaccessible to surveyors are under-sampled. Given the small size of the reserve, this is expected to have minimal impact on the results. However, it is possible that some species that were not detected may remain in these undersampled areas, albeit in small numbers. Results from the arrays will have the strongest inference in areas near the arrays. Extrapolation of results from the arrays to robust population size estimates across the entire peninsula is not possible. However, trends at the arrays can be used to identify when problems are developing, at least in the areas nearest the arrays, and used to hypothesize (infer) the status of species on the peninsula. 


\section{Improvements to the protocol}

Capture rates for all snake species were much lower than for lizards and salamanders. The ability to assess trends in ring-necked snake and southern Pacific rattlesnake were especially poor. It may be worthwhile to investigate supplementing the current monitoring methods (buckets and wire snake traps, random encounters at array sites) with additional techniques to increase detectability of snakes. Although Fitch (1992) suggests supplementing with artificial shelters such as boards about $0.75 \mathrm{~m}^{2}$, which could be checked by turning them over while at array sites. We have experimented with boards $0.09 \mathrm{~m}^{2}$ in size without improvement in capture rates. Such boards can also become shelters for Argentine ants (Robert Fisher, personal observation). However, ideas to improve detectability of snakes should continue to be explored.

\section{Recommended future analyses}

Group 1: Number of species detected, species evenness, herpetofauna captures, lizard captures, and orange-throated whiptail captures per array per year.

Two alternatives are presented for analyzing these variables. Although control limits were calculated for these variables, using an analysis of variance coupled with a contrast analysis is preferred because it will be more sensitive to detecting changes.

- Alternative 1) Conduct an analysis of variance and covariance

- Trend detection: Conduct an analysis of covariance with arrays set as a "class" variable and years set as a "regression" or "quantitative" variable. It may be more appropriate to only perform this analysis on the most recent 5-7 years.

- Comparison with baseline years: Conduct an analysis of variance with arrays and years as "class" variables. Arrays can be treated as "random" effects or as "fixed" effects. Years 1996-2000 should be considered the "base" years. A contrast analysis should be performed to test whether the results of the latest monitoring year is different from these first 5 years. (Steel and Torrie, 1980, p. 177). Differences between individual years are less important than whether a given year is different from the 5 base years.

- Alternative 2) Transform data from each new year, calculate the average per array for that year, and compare with control limits (see Table 15). If the average is outside the control limits, then the analysis of variance (Alternative 1) should also result in a significant difference detected, since the control limits are less sensitive than the analysis of variance.

- After 5 additional years of monitoring, if no trends have been discerned, the "Baseline data" years (i.e., 1996-2000) could be extended to include all 10 years, and control limits recalculated. It may even be possible to include rainfall as a covariate in the analysis.

Group 2: Snake captures per year, striped racer captures per year, number of sites with snakes present, number of sites with striped racer present, number of sites with orange-throated whiptail present, number of sites with juvenile orange-throated whiptail present.

- Trend detection: Conduct a regression analysis on the total counts per year or number of arrays that an organism is present per year with year set as a "regression" or "quantitative" variable. It may be more appropriate to perform this analysis on only the most recent 5-7 years. 
- Comparison with baseline years: Compare total count per year or number of arrays with organism present per year with control limits (see Table 15).

- After 5 years of data collection, if no trends have been discerned, recalculate the control limits.

Group 3: Striped racer juvenile counts per year, southern Pacific rattlesnake counts per year, ring-necked snake counts per year (counts include both captures and sightings of the species).

- Comparison with baseline years: If no individuals are collected that year, compare with control limits for number of zero years in a row (see Table 15).

- After 5 years of data collection, if no trends have been discerned, recalculate the control limits.

Using control limits and analyses to assist management

A summary of all the control limits calculated for analysis Groups 1,2, and 3 is given in Table 15. When a variable drops below a control limit or is found to be significant at the 5\% significance level, what this means is that given the variation seen in the baseline 5 years, we would only expect such results to occur by random chance about $5 \%$ of the time. Thus usually we conclude in natural resource management that the result did not occur by random chance and we instead accept our alternative hypothesis (i.e., that a trend is occurring). Basically in a big picture sense we are checking to see if a new year falls within a range we would expect given the amount of variation seen in the baseline 5 years.

However, it is important to realize that there is nothing "magical" about this number. These control limits and significance levels are guides to assist management but do not replace common sense. If resource managers see a problem occurring that will likely result in a decline in herpetofauna over the next several years (i.e., non-native plant invasion, new predator, increased pet collection), they should not wait until a control limit is exceeded before acting. The earlier intervention occurs, the easier and less costly it is to correct a problem. However, such interventions should be evaluated for their effectiveness and possibly set up as experiments, depending on the degree of uncertainty involved.

Similarly, a severe drought could result in a significant decline compared with the baseline years. Managers will have to decide if intervention is required to prevent species loss, or whether it is simply best to wait for higher rainfall years to return.

The five years from 1996-2000 used in this analysis include a range of weather conditions including an El Niño year in 1998 and drought years in 1996, 1999, and 2000. This variation appeared to be reflected in the large variation in captures of the 11 species and, hopefully, has improved the robustness of the sample size calculations and preliminary control limits. However, the results and conclusions should be tempered with the understanding that only 5 years of data were used and this may not encompass the full range of "naturally occurring" variation. In industry, it is preferred that $20-25$ points be gathered before calculating control limits (Montgomery 2001). In addition, it is suspected that annual rainfall may be an important cofactor, but there were not enough data to provide a good test for this. After monitoring continues for another 5 years and if no trends are detected, this sampling design optimization analysis can be repeated, control limits re-evaluated, and the number of arrays and sampling days 
needed reassessed. The relationship between capture rates of different species and annual rainfall could also be assessed.

It is important for the sake of future analyses that the same number of sampling days per year be used in all years and that sampling be conducted at roughly the same times during each year. Comparison of data in subsequent years with the 5 baseline years (1996-2000) assumes that data is collected in the same way with the same number of overall sampling days and with comparable error rates and sources of variation. If sampling is not conducted consistently, it becomes difficult to separate changes within the species from changes in the methods of collecting. Also, although snakes seen on trails while samplers go to and from the arrays should be included, herpetofauna seen during other activities such as weed control efforts, along roads, or routine maintenance should not be used in the analysis (e.g., not counted in the number of captures compared with the control limits). However, such observations are useful in other ways such as documenting where species are occurring in the preserve and the continued presence of the species in the preserve.

This analysis and resulting recommendations have assumed that a Type I error is to be preferred to a Type II error. A Type I error occurs when it is concluded that a change (decline) has occurred when in fact the results are nothing more than randomly occurring variation and no change has in fact occurred. A Type II error occurs when one concludes that no change has occurred when in fact a decline is actually happening. However, in management of sensitive species, it is better to err on the side of giving a false alert of a problem to management than to fail to detect a change. Several factors may increase the probability of a Type I error in this analysis.

- If data are highly autocorrelated (i.e., capture rates in one year are related to the capture rates in a previous year), then there can be an increased probability of a Type I error (Montgomery, 2001). This may be a small problem with this data.

- Use of Poisson regression and a Poisson distribution in the analysis of variance is to be preferred when dealing with such small whole numbers. If the analysis of variance assumes a normal distribution, there can be an increased likelihood of a Type I error. However, calculations using a Poisson distribution require sophisticated computer packages and may not change the final conclusion (i.e., that a decline is or is not occurring).

- The control limits are calculated using a Z-distribution rather than a t-distribution. While this is typical in quality control literature, this does increase the probability of a type I error.

These problems are assumed to be slight and manageable. However if "false alarms" are occurring too frequently, then analysis of variance incorporating the Poisson distribution can be used (SAS statistical software provides this option), or alternatively the $99 \%$ control limit can be used instead of the $95 \%$ control limit (i.e., an $\alpha=0.01$ rather than $\alpha=0.05$ ).

Why conduct both a regression analysis and an analysis of variance (or comparison with control limits)? If a downward trend (decline) is already occurring within the baseline data set, a regression analysis will detect this trend, whereas the control limits will be set too low, are not really valid, and will tend to cause Type II errors. However, if a trend is not occurring in the baseline data set and only starts, for example, 5 -10 years from now, the control limits will detect it more quickly. Since several variables may be showing a decline (i.e., striped racer capture 
rates, number of species detected per array per year, and number of sites occupied by orangethroated whiptail), conducting a regression analysis as well as using the control limits is advised.

\section{SUMMARY}

Only 12 of the original 19 species thought to be present at Point Loma Ecological Reserve were detected during pitfall trap sampling from 1995-2001 (see Table14) and only 11 during the actual time period used in this analysis (1996-2000). Monitoring for declines in species still present at Point Loma is necessary to provide information for timely management intervention. Striped racer captures and number of species detected per array declined from 1996 to 2000 . While striped racer declines could be caused by the snakes learning to avoid the traps, the decline is a concern and should be monitored. Declines in the number of juvenile striped racers would be especially important to track, since they will not yet have learned to avoid the traps.

The following recommendations are made for refining monitoring for herpetofauna using pitfall trap arrays at Point Loma Ecological Reserve at Point Loma, California. Refinements should provide some reduction in sampling effort while maintaining an ability to detect approximately a $20 \%$ drop in the number of species detected per array, a $40-50 \%$ drop in orange-throated whiptail (Cnemidophorus hyperythrus) capture rates, and an ability to continue monitoring trends in striped racer (Masticophis lateralis), ring-necked snake (Diadophis punctatus), and southern Pacific rattlesnake (Crotalus viridis), which were variables requested by the reserve manager.

- The number of sampling days per year could be reduced from 50 to 40.

- Only arrays \#6 and \#12 should be discontinued.

- Control limits were calculated for the various response variables (see Table 15 for a summary of all control limits).

- The 40 sampling days per year could be distributed across five 8-day sampling periods (similar to the original design of five 10-day sample periods) or alternatively across ten 4-day sampling periods with little effect on the results, provided they occur at approximately the same time during the year as the baseline data. This should allow work to be scheduled within a single work-week.

- If further reductions in sampling are required due to budget considerations, sampling the 15 arrays every other year is preferred to reducing the number of arrays further to allow sampling every year. In addition, it may be possible to reduce sampling in the JanuaryFebruary sampling period to only 4 days if tracking declines in salamanders is not a concern. Sampling in January-February should be timed after rain events to maximize detection of salamanders. 


\section{LITERATURE CITED}

Brown, C. W. and R. N. Fisher. 2002. Inventory and Management Needs Study of Point Loma Herpetofauna (Reptiles and Amphibians) with Comments on Mammals and Invertebrates, 2001. U.S. Geological Survey Technical Report. Prepared for National Park Service Cabrillo National Monument. 33 p.

Case, T. J. and R. N. Fisher. 2001. Measuring and Predicting Species Presence: Coastal Sage Scrub Case Study, pp. 47-71. In: Spatial Uncertainty in Ecology. Hunsaker, C., M. Goodchild, M. Friedl and T. Case (Eds.). Springer-Verlag, New York.

Fisher, R. N. and T. J. Case. 2000a. Distribution of the Herpetofauna of Coastal Southern California with Reference to Elevation Effects, pp. 137-143. IN: $2^{\text {nd }}$ Interface Between Ecology and Land Development in California. J.E. Keeley, M. Baer-Keeley, and C.J. Fotheringham (eds). U.S. Geological Survey Open File Report 00-62.

Fisher, R. N. and T. J. Case. 2000b. Southern California Herpetofauna Research and Monitoring: 1995-1999 Data Summation Report. U. S. Geological Survey Technical Report submitted to U.S. Fish and Wildlife Service and California Department of Fish and Game. 200 p.

Fisher, R. N., A. V. Suarez, and T. J. Case. 2002. Spatial Patterns in the Abundance of the Coastal Horned Lizard. Conservation Biology. 16(1): 205-215.

Fitch, H.S. 1992. Methods of Sampling Snake Populations and Their Relative Success. Herpetological Review. Volume 23(1): 17-19.

Geng, S. and F. J. Hills. 1989. Biometrics in Agricultural Science. Kendall/ Hunt Publishing Co. Dubuque, Iowa. $251 \mathrm{p}$.

Krebs, C. J. 1999. Ecological Methodology, $2^{\text {nd }}$ edition. Addison Wesley Longman, Inc., Menlo Park, California. $620 \mathrm{p}$.

Laakkonen, J., R. N. Fisher and T. J. Case. 2001. Effect of land cover, habitat fragmentation and ant colonies on the distribution and abundance of shrews in southern California. Journal of Animal Ecology. 70: 776-788.

Manly, B. F. J. 2001. Statistics for Environmental Science and Management. Chapman and Hall/CRC: Boca Raton, Florida. 326 p.

McBean, E. A. and F. A. Rovers. 1998. Statistical Procedures for Analysis of Environmental Monitoring Data and Risk Assessment. Prentice Hall PTR Environmental Management and Engineering Series, Vol. 3. Prentice Hall PTR, Upper Saddle River, N.J. 313 p.

Montgomery, D. C. 2001. Introduction to Statistical Quality Control, $4^{\text {th }}$ Edition. John Wiley and Sons, Inc. New York, N.Y. 796 p. 
Rochester, C. J., J.Diffendorfer, and R. N. Fisher. 2001. Natural History of the Rosy Boa (Charina trivirgata). Technical Report. Prepared for U.S. Geological Survey-Species at Risk. 71 p.

Steel, R. G. D., and J. H. Torrie. 1980. Principles and Procedures of Statistics, A Biometrical Approach, $2^{\text {nd }}$ Edition. McGraw-Hill Book Company. New York, NY. 633 p.

Stokes, D. C., C. J. Rochester, R. N. Fisher, and T. J. Case. 2004. Herpetological Monitoring Using a Pitfall Trapping Design in Southern California. DRAFT. U. S. Geological Survey Open File report. 53 p.

Thompson, W. L., G. C. White, and C. Gowan. 1998. Monitoring Vertebrate Populations. Academic Press, Inc. San Diego, California. 365 p.

Yang, B. S. and R. N. Fisher. 2003. Surveys for rare reptiles at Cabrillo National Monument on the Point Loma Peninsula in San Diego, California. U. S. Geological Survey Technical Report. Prepared for Cabrillo National Monument. 15 p.

Zar, J. H. 1999. Biostatistical Analysis, $4^{\text {th }}$ Edition. Prentice Hall, Upper Saddle River, N.J. $663 \mathrm{p}$. 
Table 3. Total herpetofauna captures per year for years 1996-2000. Data for 1995 and 2001 were excluded (see text). Recaptures within same sampling period not included. Snakes observed by surveyers while walking to and from arrays are included. The species Hypsiglena torquata (night snake) was detected in 2001. Note: 1998 was an El Niño year with elevated rainfall. The years 1996, 1999, and 2000 were considered drought years with very low rainfall.

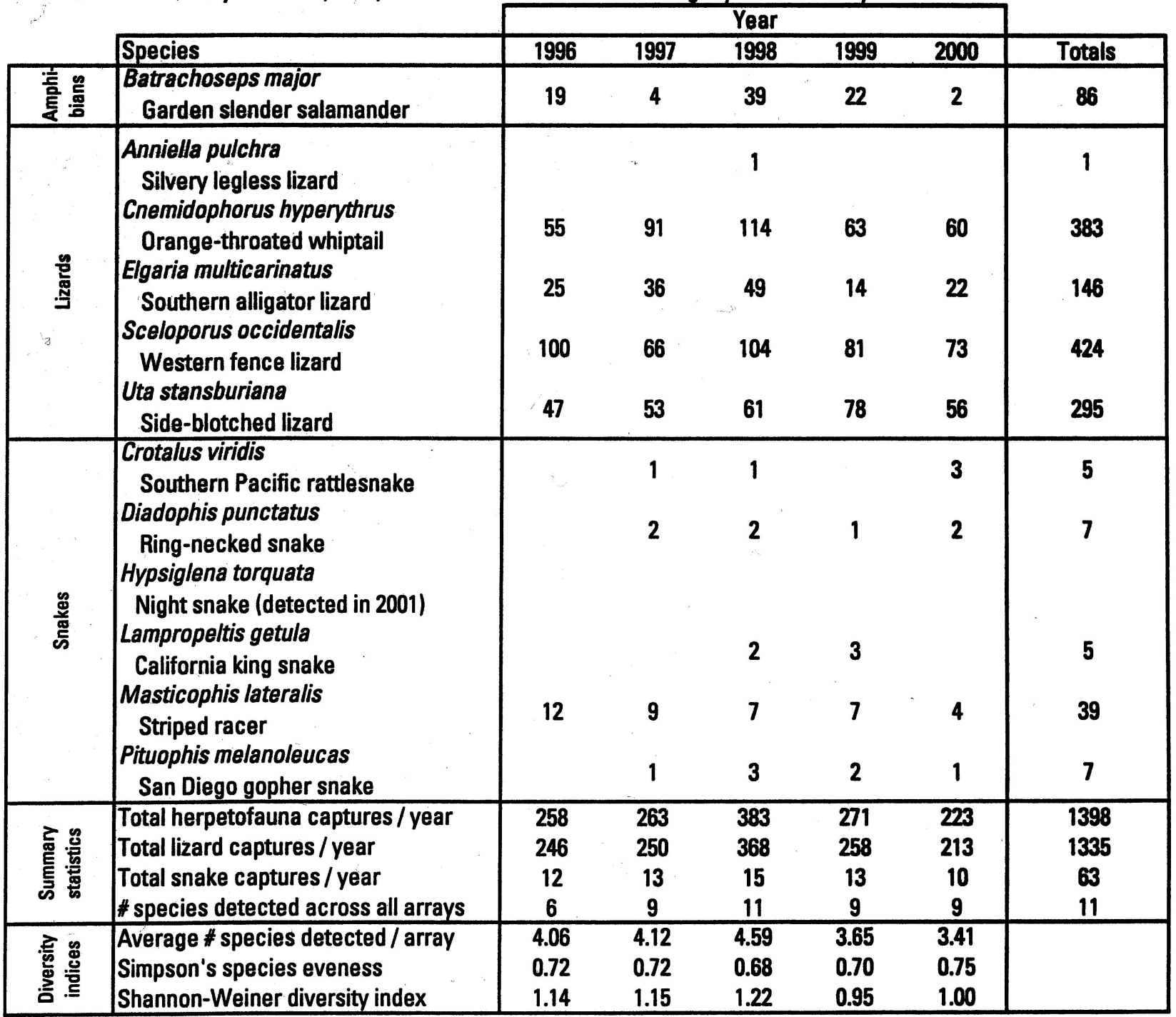


Table 4. Trend analysis and optimization analysis for average number of species detected, species evenness, total herpetofauna captures, and lizard captures per array per year. Results are presented assuming 20, 30, 40, and 50 sampling days per year (i.e., 4-day, 6-day, 8-day, or 10-day sample period). Mean Square Error (MSE) is taken from an analysis of variance which included year and array as class variables. Regression analyses were performed on all variables using the 10-day sample period data to determine if a trend existed from 1996 - 2000. All data presented have been transformed with a square root transformation, with the exception of Simpson's Eveness. Confidence Limits are given as a rough guide to determine when variables are different from baseline years, but using a contrast analysis is expected to detect a change earlier.

\begin{tabular}{|c|c|c|c|c|c|c|c|c|c|c|c|c|c|c|c|c|c|c|}
\hline & & \multicolumn{3}{|c|}{$\begin{array}{c}\text { Number spacies detected } \\
\text { \$ species/array/yr }\end{array}$} & & \multicolumn{2}{|c|}{$\begin{array}{l}\text { Simpson's Evanness } \\
\text { ovenness index/array/yr }\end{array}$} & year & & \multicolumn{2}{|c|}{$\begin{array}{l}\text { Herpetofauna capturea } \\
\text { captures/array/yr }\end{array}$} & & & $\begin{array}{l}\text { Lizard } \\
\text { aptur } \\
\text { Ipling }\end{array}$ & $\begin{array}{l}\text { aptur: } \\
\text { Jarray }\end{array}$ & \\
\hline & & & 20 & 30 & 40 & 50 & 20 & 30 & 40 & 50 & 20 & 30 & 40 & 50 & 20 & 30 & 40 & 50 \\
\hline \multirow{5}{*}{ 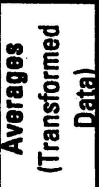 } & \multirow{5}{*}{\multicolumn{2}{|c|}{$\begin{array}{l}1996 \\
1997 \\
1998 \\
1999 \\
2000\end{array}$}} & 1.65 & 1.81 & 1.92 & 1.99 & 0.85 & 0.81 & 0.75 & 0.72 & 2.57 & 2.97 & 3.41 & 3.78 & 2.40 & 2.80 & 3.18 & 3.52 \\
\hline & & & 1.71 & 1.88 & 1.96 & 2.00 & 0.82 & 0.78 & 0.75 & 0.72 & 2.49 & 3.07 & 3.43 & 3.75 & 2.34 & 2.92 & 3.26 & 3.57 \\
\hline & & & 1.88 & 1.98 & 2.03 & 2.12 & 0.76 & 0.72 & 0.71 & 0.68 & 3.08 & 3.90 & 4.25 & 4.61 & 2.84 & 3.59 & 3.88 & 4.22 \\
\hline & & & 1.59 & 1.73 & 1.85 & 1.87 & 0.83 & 0.77 & 0.73 & 0.70 & 2.74 & 3.15 & 3.47 & 3.79 & 2.53 & 2.90 & 3.18 & 3.48 \\
\hline & & & 1.49 & 1.67 & 1.74 & 1.82 & 0.89 & 0.83 & 0.78 & 0.75 & 2.12 & 2.72 & 3.12 & 3.42 & 2.04 & 2.63 & 3.01 & 3.32 \\
\hline \multirow{3}{*}{ 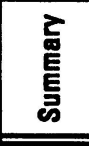 } & \multirow{3}{*}{\multicolumn{2}{|c|}{\begin{tabular}{|l|} 
average \\
MSE \\
CV \\
Transformation \\
\end{tabular}}} & $\begin{array}{l}1.66 \\
0.12\end{array}$ & 1.81 & 1.90 & 1.96 & $\begin{array}{l}0.829 \\
0.016\end{array}$ & 0.781 & 0.746 & 0.715 & 2.60 & 3.16 & 3.53 & 3.87 & 2.43 & 2.97 & & 3.62 \\
\hline & & & 0.21 & 0.18 & 0.16 & 0.14 & 0.150 & 0.188 & 0.210 & 0.201 & $\begin{array}{l}0.40 \\
0.26\end{array}$ & $\begin{array}{l}0.45 \\
0.21\end{array}$ & $\begin{array}{l}0.39 \\
0.18\end{array}$ & $\begin{array}{l}0.40 \\
0.16\end{array}$ & $\begin{array}{l}0.46 \\
0.28\end{array}$ & $\begin{array}{l}0.41 \\
0.22\end{array}$ & $\begin{array}{l}0.38 \\
0.19\end{array}$ & $\begin{array}{l}0.36 \\
0.17\end{array}$ \\
\hline & & & & & eroo & & & & $\ldots$ & & & squ & root & & & & e root & \\
\hline 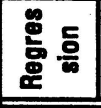 & \multicolumn{2}{|c|}{\begin{tabular}{|l|} 
Is trend present? \\
slope \\
prob.>|t|
\end{tabular}} & \multicolumn{4}{|c|}{$\begin{array}{c}\text { yes } \\
-0.048 \\
p=0.0370 \\
\end{array}$} & \multicolumn{4}{|c|}{ not significant } & \multicolumn{4}{|c|}{ not significant } & \multicolumn{4}{|c|}{ not significant } \\
\hline \multirow{3}{*}{ 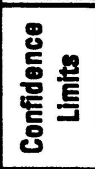 } & \multirow{3}{*}{\multicolumn{2}{|c|}{$\begin{array}{l}\text { upper 99\% CL } \\
\text { upper 95\% CL } \\
\text { lower 95\% CL } \\
\text { lower } 99 \% \mathrm{CL}\end{array}$}} & $\begin{array}{l}.03 \\
1.94\end{array}$ & $\begin{array}{l}2.13 \\
2.05\end{array}$ & $\begin{array}{l}2.19 \\
2.12\end{array}$ & $\begin{array}{l}2.27 \\
2.20\end{array}$ & $\begin{array}{l}0.95 \\
0.92\end{array}$ & $\begin{array}{l}0.89 \\
0.87\end{array}$ & $\begin{array}{l}0.81 \\
0.80\end{array}$ & $\begin{array}{l}0.78 \\
0.77\end{array}$ & $\begin{array}{l}3.51 \\
3.29\end{array}$ & $\begin{array}{l}4.31 \\
4.03\end{array}$ & $\begin{array}{l}4.62 \\
4.36\end{array}$ & $\begin{array}{l}5.00 \\
4.73\end{array}$ & $\begin{array}{l}3.19 \\
3.01\end{array}$ & $\begin{array}{l}3.91 \\
3.68\end{array}$ & $\begin{array}{l}4.16 \\
3.96\end{array}$ & $\begin{array}{l}4.52 \\
4.30\end{array}$ \\
\hline & & & 1.38 & 1.57 & 1.69 & 1.73 & 0.74 & 0.70 & 0.70 & 0.66 & 1.91 & 2.29 & 2.70 & 3.01 & 1.86 & 2.25 & 2.65 & 2.94 \\
\hline & & & 1.29 & 1.50 & 1.62 & 1.65 & 0.71 & 0.67 & 0.68 & 0.65 & 1.69 & 2.02 & 2.44 & 2.74 & 1.68 & 2.03 & 2.44 & 2.73 \\
\hline \multirow{16}{*}{ 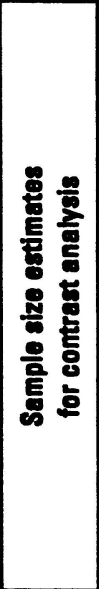 } & Power & $\begin{array}{c}\text { Difference } \\
\text { to detect }\end{array}$ & \multicolumn{16}{|c|}{$\begin{array}{l}\text { * arrays recommended at given power and } 0.05 \text { alpha level } \\
\text { (Cells in gray would require an increase in number of arrays) }\end{array}$} \\
\hline & & $30 \%$ & 11 & 8 & 7 & 6 & 6 & 9 & 11 & 10 & 17 & 11 & 8 & 7 & 19 & 12 & 9 & 7 \\
\hline & & $40 \%$ & 7 & 5 & 4 & 4 & 4 & 6 & 7 & 6 & 10 & 7 & 5 & 4 & 11 & 7 & 6 & 5 \\
\hline & 登 & $50 \%$ & 5 & 4 & 3 & 3 & 3 & 4 & 5 & 4 & 7 & 5 & 4 & 3 & 7 & 5 & 4 & 3 \\
\hline & & $60 \%$ & 4 & 3 & 3 & 2 & 3 & 3 & 4 & 3 & 5 & 4 & 3 & 3 & 5 & 4 & 3 & 3 \\
\hline & & $70 \%$ & 3 & 3 & 2 & 2 & 2 & 3 & 3 & 3 & 4 & 3 & 3 & 2 & 4 & 4 & 3 & 2 \\
\hline & & $30 \%$ & 8 & 7 & 5 & 5 & 5 & 7 & 9 & 8 & 13 & 8 & 6 & 6 & 14 & 9 & 7 & 6 \\
\hline & & $40 \%$ & 5 & 4 & 4 & 3 & 3 & 4 & 5 & 5 & 8 & 5 & 4 & 4 & 8 & 5 & 4 & 4 \\
\hline & 8 & $50 \%$ & 4 & 3 & 3 & 3 & 3 & 3 & 4 & 4 & 5 & 4 & 3 & 3 & 6 & 4 & 3 & 3 \\
\hline & & $60 \%$ & 3 & 3 & 2 & 2 & 2 & 3 & 3 & 3 & 4 & 3 & 3 & 2 & 4 & 3 & 3 & 2 \\
\hline & & $70 \%$ & 3 & 2 & 2 & 2 & 2 & 2 & 3 & 2 & 3 & 3 & 2 & 2 & 4 & 3 & 2 & 2 \\
\hline & & $30 \%$ & 7 & 5 & 5 & 4 & 4 & 6 & 7 & 6 & 10 & 7 & 5 & 5 & 11 & 7 & 6 & 5 \\
\hline & & $40 \%$ & 4 & 4 & 3 & 3 & 3 & 4 & 4 & 4 & 6 & 4 & 3 & 3 & 7 & 5 & 4 & 3 \\
\hline & ह & $50 \%$ & 3 & 3 & 2 & 2 & 2 & 3 & 3 & 3 & 4 & 3 & 3 & 3 & 5 & 3 & 3 & 3 \\
\hline & & $60 \%$ & 3 & 2 & 2 & 2 & 2 & 2 & 3 & 3 & 3 & 3 & 2 & 2 & 4 & 3 & 2 & 2 \\
\hline & & $70 \%$ & 2 & 2 & 2 & 2 & 2 & 2 & 2 & 2 & 3 & 2 & 2 & 2 & 3 & 2 & 2 & 2 \\
\hline
\end{tabular}


Table 5. Trend analysis and optimization analysis for orange-throated whiptail captures and juvenile orange-throated whiptail captures per array per year. Results are presented assuming 20, 30, 40, and 50 sampling days per year (i.e., 4-day, 6-day, 8-day, or 10-day sample period). Mean Square Error (MSE) is taken from an analysis of variance which included year and array as class variables. Regression analyses were performed on all variables using the 10-day sample period data to determine if a trend already existed from 1996 - 2000. All data presented have been transformed with a square root transformation. Confidence Limits are given as a rough guide to determine when variables are different from baseline years, but using a contrast analysis is expected to detect a change earlier. Results for orangethroated whiptails are presented with data from all arrays included and again with only arrays that had $>2$ captures of whiptails.

\begin{tabular}{|c|c|c|c|c|c|c|c|c|c|c|c|c|c|}
\hline & \multicolumn{4}{|c|}{$\begin{array}{l}\text { Orange throated whiptail } \\
\text { All Arrays } \\
\text { sampling days per year }\end{array}$} & \multicolumn{4}{|c|}{$\begin{array}{l}\text { Orange throated whiptail } \\
\text { Arrays 1-4, 9-10,13-17 } \\
\text { sampling days per year }\end{array}$} & \multicolumn{4}{|c|}{$\begin{array}{l}\text { Juv. Orange throated whiptail } \\
\text { Arrays 1-4, 9-10,13-17 } \\
\text { sampling days per year }\end{array}$} \\
\hline & & 20 & 30 & 40 & 50 & 20 & 30 & 40 & 50 & & $30^{\circ}$ & 40 & 50 \\
\hline \multirow{5}{*}{ 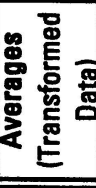 } & & 0.76 & 0.95 & 1.25 & 1.41 & 1.18 & 1.37 & 1.85 & 2.00 & 0.47 & 0.60 & 0.75 & 0.89 \\
\hline & 1997 & 1.05 & 1.40 & 1.60 & 1.70 & 1.63 & 2.07 & 2.38 & 2.54 & 0.94 & 1.27 & 1.41 & 1.52 \\
\hline & 1998 & 1.37 & 1.76 & 1.84 & 2.00 & 2.02 & 2.64 & 2.75 & 3.00 & 1.11 & 1.49 & 1.53 & 1.64 \\
\hline & 1999 & 1.10 & 1.23 & 1.33 & 1.40 & 1.69 & 1.90 & 2.05 & 2.16 & 0.66 & 0.71 & 0.80 & 0.82 \\
\hline & 2000 & 0.55 & 0.87 & 1.07 & 1.22 & 0.55 & 1.26 & 1.57 & 1.79 & 0.18 & 0.27 & 0.53 & 0.64 \\
\hline \multirow{4}{*}{$\begin{array}{l}\text { Z्ञ } \\
\text { E्ञ } \\
\text { E } \\
\end{array}$} & average & 0.96 & 1.24 & 1.42 & 1.55 & $\overline{1.47}$ & $\overline{1.85}$ & 2.12 & 2.30 & 0.69 & $\overline{0.87}$ & 1.00 & $\overline{1.10}$ \\
\hline & MSE & 0.32 & 0.46 & 0.43 & 0.46 & 0.42 & 0.55 & 0.54 & 0.56 & 0.26 & 0.26 & 0.35 & 0.34 \\
\hline & & 0.58 & & 0.46 & 0.44 & 0.44 & & & 0.32 & 0.74 & & 0.59 & 0.53 \\
\hline & Transformation & \multicolumn{4}{|c|}{ square root } & \multicolumn{4}{|c|}{ square root } & & & & \\
\hline 遣 & $\begin{array}{l}\text { Is trend present? } \\
\text { slope } \\
\text { prob. }>|t|\end{array}$ & & & ifican & & & notsi & ifican & & \multicolumn{4}{|c|}{$\begin{array}{c}\text { maybe } \\
-0.12 \\
p=0.0792\end{array}$} \\
\hline \multirow{4}{*}{ 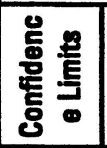 } & upper $99 \% \mathrm{CL}$ & & & 2.19 & & & 3.29 & 3.30 & $\overline{3.53}$ & 1.65 & 2.1 & 2.13 & 2.25 \\
\hline & upper 95 & 1.59 & 1.95 & 2.01 & 2.15 & 2.59 & 2.94 & 3.02 & 3.2 & 1.42 & 18 & 1.86 & 1.97 \\
\hline & & $\begin{array}{l}0.34 \\
0\end{array}$ & 0.54 & 0.83 & 0.95 & 0.36 & 0.75 & 1.22 & 1.36 & -0.04 & -0.11 & 0.14 & 0.23 \\
\hline & lower $99 \%$ CL & & 0.31 & 0.64 & 0.76 & 0.01 & 0.41 & 0.93 & 1.07 & -0.27 & -0.42 & -0.13 & 0.05 \\
\hline
\end{tabular}

\begin{tabular}{|c|c|c|c|c|c|c|c|c|c|c|c|c|c|c|}
\hline & Power & $\begin{array}{c}\text { Difference } \\
\text { to detect }\end{array}$ & & & & ing & Noul & quir & inc & T & bero & $\begin{array}{l}\text { zvel } \\
\text { aysl }\end{array}$ & & \\
\hline & & $30 \%$ & 80 & 71 & 51 & 46 & 46 & 38 & 29 & 25 & 130 & 83 & 82 & 67 \\
\hline & & $40 \%$ & 45 & 40 & 29 & 26 & 26 & 22 & 17 & 15 & 74 & 47 & 47 & 38 \\
\hline & 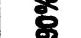 & $50 \%$ & 29 & 26 & 19 & 17 & 17 & 14 & 11 & 10 & 47 & 30 & 30 & 25 \\
\hline & & $60 \%$ & 21 & 18 & 13 & 12 & 12 & 10 & 8 & 7 & 33 & 21 & 21 & 17 \\
\hline & & $70 \%$ & 15 & 14 & 10 & 9 & 9 & 8 & 6 & 5 & 25 & 16 & 16 & 13 \\
\hline & & $30 \%$ & 60 & 53 & 38 & 34 & 35 & 29 & 22 & 19 & 97 & 62 & 62 & 50 \\
\hline 5 & & $40 \%$ & 34 & 30 & 22 & 20 & 20 & 17 & 13 & 11 & 55 & 35 & 35 & 29 \\
\hline & 応 & $50 \%$ & 22 & 20 & 14 & 13 & 13 & 11 & 8 & 8 & 36 & 23 & 23 & 19 \\
\hline & & $60 \%$ & 16 & 14 & 10 & 9 & 9 & 8 & 6 & 6 & 25 & 16 & 16 & 13 \\
\hline & & $70 \%$ & 12 & 10 & 8 & 7 & 7 & 6 & 5 & 4 & 19 & 12 & 12 & 10 \\
\hline & & $30 \%$ & 48 & 42 & 30 & 27 & 28 & 23 & 17 & 15 & 77 & 49 & 49 & 40 \\
\hline & & $40 \%$ & 27 & 24 & 17 & 16 & 16 & 13 & 10 & 9 & 44 & 28 & 28 & 23 \\
\hline & 登 & $50 \%$ & 18 & 16 & 12 & 11 & 11 & 9 & 7 & 6 & 28 & 18 & 18 & 15 \\
\hline & & $60 \%$ & 13 & 11 & 8 & 8 & 8 & 6 & 5 & 5 & 20 & 13 & 13 & 11 \\
\hline & & $70 \%$ & 9 & 9 & 6 & 6 & 6 & 5 & 4 & 4 & 15 & 10 & 10 & 8 \\
\hline
\end{tabular}


Table 6. Calculation of $95 \%$ and $99 \%$ confidence levels for total number of snake captures per year, striped racer captures per year, and number of arrays occupied by snakes, striped racers only, orange-throated whiptails and juvenile orange-throated whiptails. Results are presented assuming 20, 30, 40, and 50 sample days per year (i.e. a 4-day, 6-day, 8-day, or 10-day sample period). The type of distribution determined the method of calculation for confidence limits (Poisson, normal). Warning limits are the $90 \%$ and $95 \%$ confidence limits converted to whole numbers of individuals captured or numbers of arrays with individuals present. Regression analyses were conducted on all variables using the 10-day sample period data to determine if a trend already existed from $1996-2000$.

\begin{tabular}{|c|c|c|c|c|c|c|c|c|c|c|c|c|c|c|c|c|c|c|c|c|c|c|c|c|c|}
\hline \multirow{3}{*}{\multicolumn{2}{|c|}{$\begin{array}{l}\text { Response variable= } \\
\text { Sampling days per year }=\end{array}$}} & \multicolumn{8}{|c|}{ All enakes } & \multicolumn{8}{|c|}{ Striped Recer } & \multirow{2}{*}{\multicolumn{4}{|c|}{ 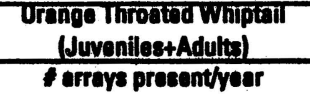 }} & \multirow{2}{*}{\multicolumn{4}{|c|}{ 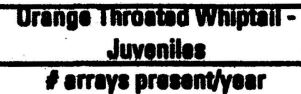 }} \\
\hline & & \multirow{2}{*}{\multicolumn{4}{|c|}{ Captureadyear }} & \multirow{2}{*}{\multicolumn{4}{|c|}{ I arraye presentyoer }} & \multirow{2}{*}{\multicolumn{4}{|c|}{20 enptures/vear }} & \multicolumn{4}{|c|}{ f arraye present/year } & & & & & & & & \\
\hline & & & & 40 & 50 & & & & & & & & & 20 & $30^{\circ}$ & 40 & 50 & 20 & 30 & 40 & 50 & 20 & 30 & 40 & 50 \\
\hline \multirow{5}{*}{ 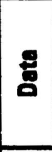 } & 1996 & 4 & 5 & 9 & 12 & 3 & 4 & 6 & 8 & 4 & 5 & 9 & 12 & 3 & 4 & 6 & 8 & 8 & 10 & 12 & 13 & 4 & 5 & $\frac{6}{6}$ & 7 \\
\hline & 1997 & 8 & 9 & 11 & 13 & 8 & 9 & 9 & 9 & 7 & 8 & 9 & 9 & 7. & 8 & 9 & 9 & 8 & 10 & 11 & 11 & 8 & 8 & 8 & 9 \\
\hline & 1998 & 6 & 9 & 11 & 15 & 6 & 9 & 10 & 12 & 3 & 3 & 5 & 7 & 3 & 3 & 5 & 6 & 11 & 11 & 11 & 12 & 7 & 9 & 9 & 9 \\
\hline & 1999 & 7 & 8 & 11 & 12 & 4 & 5 & 6 & 7 & 3 & 4 & 6 & 7 & 3 & 4 & 5 & 6 & 10 & 11 & 11 & 11 & 5 & 5 & 6 & 6 \\
\hline & 2000 & 3 & 5 & 8 & 8 & 3 & 4 & 5 & 5 & 0 & 2 & 4 & 4 & 0 & 2 & 4 & 4 & 6 & 8 & 9 & 10 & 2 & 2 & 4 & 4 \\
\hline \multirow{5}{*}{ 总 } & Taverage & 5.6 & 7.2 & 10.0 & 12.0 & 4.8 & 6.2 & $\overline{7.2}$ & $\overline{8.2}$ & 3.4 & 4.4 & 6 & 7.8 & 3.2 & $\overline{4.2}$ & $\overline{5.8}$ & 6.6 & 8.6 & 10.0 & 10.8 & 11.4 & 5.2 & 5.8 & 6.6 & 7.0 \\
\hline & Std. Dev. & 2.1 & 2.0 & & 2.5 & 2.2 & 2.6 & 2.2 & 2.6 & 2.5 & 2.3 & 2.3 & 2.9 & 2.5 & 2.3 & 1.9 & 1.9 & 1.9 & 1.2 & 1.1 & 1.1 & 2.4 & 2.8 & 1.9 & 2.1 \\
\hline & Variance & 4.3 & 4.2 & 2.0 & 6.5 & 4.7 & 6.7 & 4.7 & 6.7 & 6.3 & 5.3 & 5.3 & 8.7 & 6.2 & 5.2 & 3.7 & 3.8 & 3.8 & 1.5 & 1.2 & 1.3 & 5.7 & 7.7 & 3.8 & 4.5 \\
\hline & CV & 0.37 & 0.28 & 0.14 & 0.21 & 0.45 & 0.42 & & 0.32 & 0.74 & & 0.35 & 0.38 & 0.78 & 0.54 & & 0.30 & 0.23 & 0.12 & 0.10 & 0.10 & 0.46 & & 0.30 & 0.30 \\
\hline & Type of distribution & \multicolumn{4}{|c|}{ Poisson } & \multicolumn{4}{|c|}{ Poisson } & & Poi & & & & & & & & & & & & & 800 & \\
\hline 串 & $\begin{array}{l}\text { Trend present? } \\
\text { prob.>|t| }\end{array}$ & & not si & ificant & & & not sit & ificant & & \multicolumn{4}{|c|}{$\begin{array}{c}\text { yes } \\
0.0079\end{array}$} & \multicolumn{4}{|c|}{$\begin{array}{c}\text { yos } \\
0.0418\end{array}$} & \multicolumn{4}{|c|}{$\begin{array}{l}\text { maybe } \\
0.00055\end{array}$} & \multicolumn{4}{|c|}{ not significant } \\
\hline \multirow{6}{*}{ 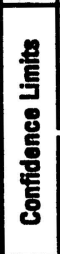 } & upper $99 \% \mathrm{CL}$ & 14.9 & 17.1 & 21.4 & 24.1 & 13.4 & 15.7 & 17.1 & 18.6 & 11.0 & 12.6 & $\overline{16.4}$ & $\overline{177.9}$ & 111.0 & 12.6 & 14.9 & 16.4 & 13.6 & 13.2 & 13.6 & 14.3 & 14.1 & 14.9 & 18.4 & 17.1 \\
\hline & upper 95\% CL & 12.4 & 14.4 & 18.4 & 21.0 & 11.0 & 13.1 & 14.4 & 15.8 & 8.8 & 10.2 & 13.7 & 15.1 & 8.8 & 10.2 & 12.4 & 13.7 & 12.4 & 12.4 & 12.9 & 13.6 & 11.7 & 12.4 & 13.7 & 14.4 \\
\hline & lower 95\% CL & 1.9 & 2.8 & 4.8 & 6.2 & 1.4 & 2.2 & 2.8 & 3.5 & 0.6 & 1.1 & 2.5 & 3.1 & 0.6 & 1.1 & 1.9 & 2.5 & 4.8 & 7.6 & 8.7 & 9.2 & 1.6 & $\begin{array}{l}1.9 \\
1.9\end{array}$ & 2.5 & 28 \\
\hline & Lower 99\% CL & 1.3 & 2.0 & 3.7 & 4.9 & 0.9 & 1.5 & 2.0 & 2.6 & 0.3 & 0.7 & 1.8 & 2.3 & 0.3 & 0.7 & 1.3 & 1.8 & 3.6 & 6.8 & 8.0 & 8.5 & 1.1 & 1.3 & 1.8 & 20 \\
\hline & $\begin{array}{l}\text { Werning }-95 \% \text { CL ** } \\
\text { (* captures or } f \text { arrays) }\end{array}$ & 1 & 2 & 4 & 6 & 1 & 2 & 2 & 3 & 0 & 1 & 2 & 3 & 0 & 1 & 1 & 2 & 4 & 7 & 8 & 9 & 1 & 1 & 2 & 2 \\
\hline & Warning & 1 & 2 & 3 & 4 & 0 & 1 & 2 & 2 & 0 & 0 & 1 & 2 & 0 & 0 & 1 & 1 & 3 & 6 & 7 & 8 & 1 & 1 & 1 & 2 \\
\hline
\end{tabular}

* Calculation of "Thresholds" is based on the essumption that variation occuring during 1996-2000 is randomly occuring variation. If a trend is in fact occuring during that time period, then the thresholds are not valio. 
Table 7. Calculation of control limits for juvenile striped racers, ring-necked snakes and southern Pacific rattlesnake. Control limits were determined as the point when the probability for multiple years in a row with zero captures or sightings of these snakes at the pitfall trap arrays drops below $5 \%$. One capture was added and subtracted to each calculation to determine how robust the calculation was, and the control limits were expanded accordingly. (Numbers remain the same if array $\$ 6$ and $\$ 12$ are dropped from the analysis since none of these snakes were found in array $\# 6$ or $\# 12$.)

\begin{tabular}{|c|c|c|c|c|c|c|c|c|c|c|c|c|c|}
\hline \multirow{3}{*}{\multicolumn{2}{|c|}{ Year }} & \multicolumn{12}{|c|}{ Number captures and sightings at arrays / year } \\
\hline & & \multicolumn{4}{|c|}{$\begin{array}{l}\text { Juvenile Striped Racer } \\
\text { Masticophis lateralis }\end{array}$} & \multicolumn{4}{|c|}{$\begin{array}{l}\text { Ring-necked Snake } \\
\text { Diadophis punctatus }\end{array}$} & \multicolumn{4}{|c|}{$\begin{array}{c}\text { Southern Pacific Rattlesnake } \\
\text { Crotalus viridis }\end{array}$} \\
\hline & & 20 days $/ y r$ & 30 days/yr & 40 days/yr & 50 days/yr & 20 days/yr & 30 days/yr & 40 days/yr & 50 days/yr & 20 days/yr & 30 days/yr & 40 days/yr & 50 days/yr \\
\hline 1996 & & 1 & 1 & 1 & 2 & 0 & 0 & 0 & 0 & 0 & 0 & 0 & 0 \\
\hline 1997 & & 2 & 2 & 2 & 2 & 0 & 0 & 1 & 2 & 0 & 0 & 0 & 1 \\
\hline 1998 & & 0 & 0 & 1 & 1 & 1 & 2 & 2 & 2 & 1 & 1 & 1 & 1 \\
\hline 1999 & & 1 & 2 & 2 & 2 & 0 & 0 & 1 & 1 & 0 & 0 & 0 & 0 \\
\hline 2000 & & 0 & 1 & 1 & 1 & 1 & 1 & 2 & 2 & 3 & 3 & 3 & 3 \\
\hline $\begin{array}{c}\text { Total } \\
\text { Averaga }\end{array}$ & & $\begin{array}{c}4 \\
0.8\end{array}$ & $\begin{array}{c}6 \\
12\end{array}$ & $\begin{array}{c}7 \\
14\end{array}$ & $\begin{array}{c}8 \\
16\end{array}$ & 2 & $\begin{array}{c}3 \\
06\end{array}$ & 6 & 7 & 4 & $\begin{array}{c}4 \\
08\end{array}$ & 4 & 5 \\
\hline $\begin{array}{l}\text { Probability of zero } \\
\text { cantures } P(0)\end{array}$ & & 0.4493 & 0.3012 & 0.2466 & 0.2019 & 0.6703 & 0.5488 & 0.3012 & 0.2466 & 0.4493 & 0.4493 & 0.4493 & 0.3679 \\
\hline $\begin{array}{l}\text { Probability of multiple } \\
\text { years with zero } \\
\text { captures in a row }\end{array}$ & $\begin{array}{l}1 \text { year } \\
2 \text { years } \\
3 \text { years } \\
4 \text { years } \\
5 \text { years } \\
6 \text { years } \\
7 \text { years }\end{array}$ & $\begin{array}{l}0.4493 \\
0.2019 \\
0.0907 \\
0.0408 \\
0.0183 \\
0.0082 \\
0.0037\end{array}$ & $\begin{array}{l}0.3012 \\
0.0907 \\
0.0273 \\
0.0082 \\
0.0025 \\
0.0007 \\
0.0002\end{array}$ & $\begin{array}{l}0.2466 \\
0.0608 \\
0.0150 \\
0.0037 \\
0.0009 \\
0.0002 \\
0.0001\end{array}$ & $\begin{array}{l}0.2019 \\
0.0408 \\
0.0082 \\
0.0017 \\
0.0003 \\
0.0001 \\
0.0000\end{array}$ & $\begin{array}{l}0.6703 \\
0.4493 \\
0.3012 \\
0.2019 \\
0.1353 \\
0.0907 \\
0.0608\end{array}$ & $\begin{array}{l}0.5488 \\
0.3012 \\
0.1653 \\
0.0907 \\
0.0498 \\
0.0273 \\
0.0150\end{array}$ & $\begin{array}{l}0.3012 \\
0.0907 \\
0.0273 \\
0.0082 \\
0.0025 \\
0.0007 \\
0.0002\end{array}$ & $\begin{array}{l}0.2466 \\
0.0608 \\
0.0150 \\
0.0037 \\
0.0009 \\
0.0002 \\
0.0001\end{array}$ & $\begin{array}{l}0.4493 \\
0.2019 \\
0.0907 \\
0.0408 \\
0.0183 \\
0.0082 \\
0.0037\end{array}$ & $\begin{array}{l}0.4493 \\
0.2019 \\
0.0907 \\
0.0408 \\
0.0183 \\
0.0082 \\
0.0037\end{array}$ & $\begin{array}{l}0.4493 \\
0.2019 \\
0.0907 \\
0.0408 \\
0.0183 \\
0.0082 \\
0.0037\end{array}$ & $\begin{array}{l}0.3679 \\
0.1353 \\
0.0498 \\
0.0183 \\
0.0067 \\
0.0025 \\
0.0009\end{array}$ \\
\hline $\begin{array}{l}\text { Control Limit : } ₹ \text { of year: } \\
\text { zero captures or sightin } \\
\text { arrays = }\end{array}$ & $\begin{array}{l}\text { with } \\
\text { gs at }\end{array}$ & $3-5$ years & 3 years & $2-3$ years & $2-3$ years & 5-? years & 4-8 years & 3 years & 2-3 years & $3-5$ years & $3-5$ years & $3-5$ years & 3-4 years \\
\hline
\end{tabular}


Table 8. Captures during each day in sample period summed across all sampling periods from 1996-2000. The rate of new captures declines as the day in the sampling period progresses.

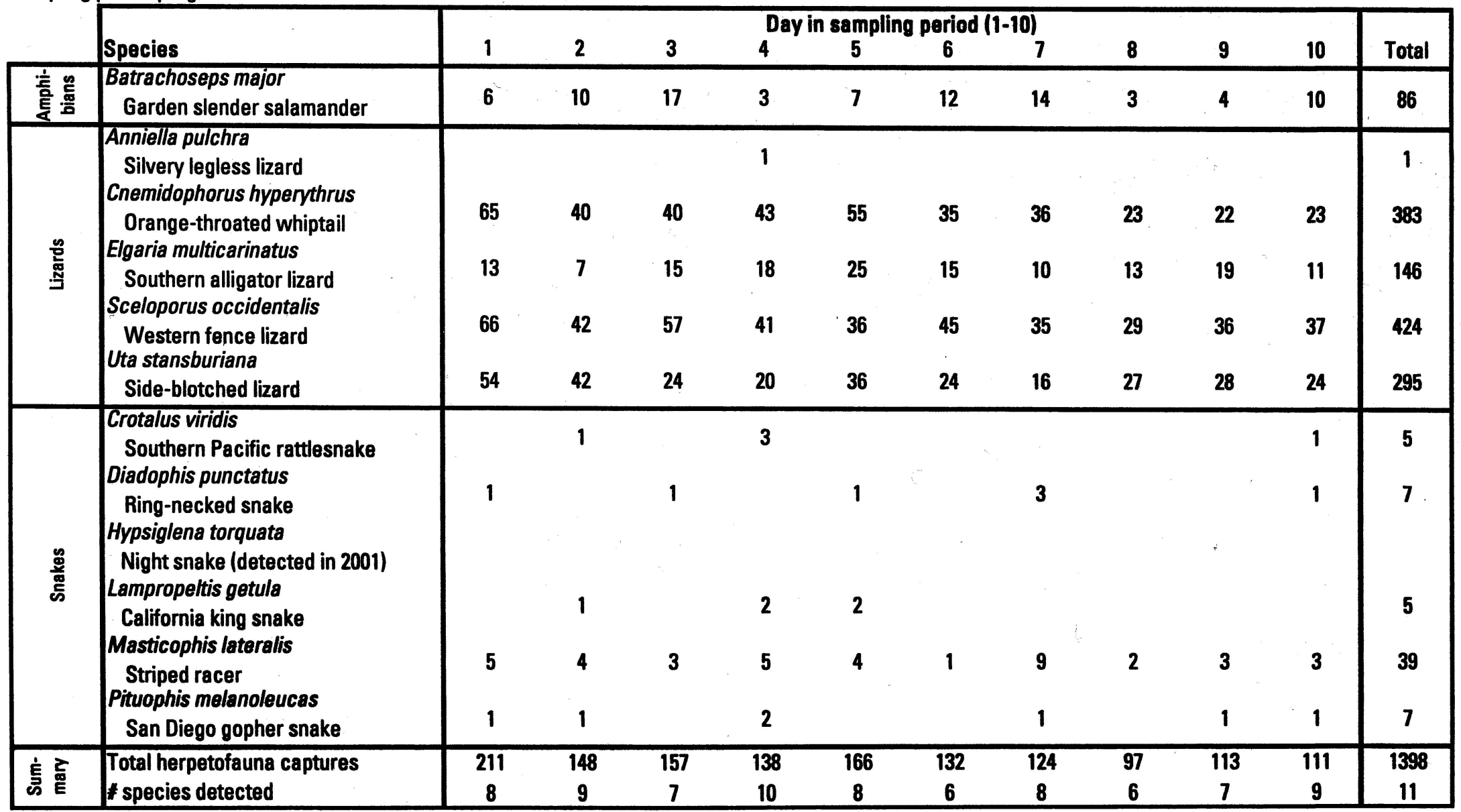


Table 9. Total herpetofauna captures per array for years $1996-2000$. Recaptures within same sampling period are not included. Array $\# 6$ and array $\# 12$ could be discontinued. Three snake observations were not recorded with an array number and were seen while walking on trails to arrays.

\begin{tabular}{|c|c|c|c|c|c|c|c|c|c|c|c|c|c|c|c|c|c|c|c|}
\hline & \multicolumn{18}{|c|}{ Array } & \multirow[b]{2}{*}{ Total } \\
\hline Species & 1 & 2 & 3 & 4 & 5 & 6 & 7 & 8 & 9 & 10 & 11 & 12 & 13 & 14 & 15 & 16 & 17 & Not Recorded & \\
\hline $\begin{array}{l}\text { Batrachoseps major } \\
\text { Garden slender salamander }\end{array}$ & & 3 & & & & 2 & 8 & 5 & 35 & 2 & 19 & 4 & 1 & 3 & & 1 & 3 & & 86 \\
\hline $\begin{array}{l}\text { Anniella pulchra } \\
\text { Silvery legless lizard }\end{array}$ & & & 1 & & & & & & & & & & & & & & & & 1 \\
\hline $\begin{array}{l}\text { Cnemidophorus hyperythrus } \\
\text { Orange-throated whiptail }\end{array}$ & 59 & 22 & 112 & 41 & 1 & 1 & & & 14 & 6 & 2 & 1 & 27 & 43 & 21 & 23 & 10 & & 383 \\
\hline $\begin{array}{l}\text { Elgaria multicarinatus } \\
\text { Southern alligator lizard }\end{array}$ & 9 & 15 & 22 & 14 & 2 & & 5 & 2 & 5 & 7 & 8 & 9 & 22 & 8 & 10 & 5 & 3 & & 146 \\
\hline $\begin{array}{l}\text { Sceloporus occidentalis } \\
\text { Western fence lizard }\end{array}$ & 17 & 8 & 40 & 34 & 20 & 12 & 27 & 20 & 25 & 9 & 16 & 15 & 41 & 53 & 27 & 30 & 30 & & 424 \\
\hline $\begin{array}{l}\text { Uta stansburiana } \\
\text { Side-blotched lizard }\end{array}$ & 3 & 27 & 22 & 14 & 39 & 54 & 8 & 3 & 1 & 3 & 1 & 1 & 13 & 34 & 32 & 21 & 19 & & 295 \\
\hline $\begin{array}{l}\text { Crotalus viridis } \\
\text { Southern Pacific rattlesnake }\end{array}$ & & & & & & & & & & 1 & & & 1 & & 1 & & & 2 & 5 \\
\hline $\begin{array}{l}\text { Diadophis punctatus } \\
\text { Ring-necked snake }\end{array}$ & & & & & & & & 1 & 2 & & 2 & & & & & & 1 & 1 & 7 \\
\hline $\begin{array}{l}\text { Lampropeltis getula } \\
\text { California king snake }\end{array}$ & & 1 & 2 & 1 & & & & & & & & & 1 & & & & & & 5 \\
\hline $\begin{array}{l}\text { Masticophis lateralis } \\
\text { Striped racer }\end{array}$ & 3 & & 3 & 1 & 4 & & 3 & 3 & 7 & 3 & 1 & 1 & 3 & 3 & 3 & & 1 & . & 39 \\
\hline $\begin{array}{l}\text { Pituophis melanoleucas } \\
\text { San Diego gopher snake }\end{array}$ & 1 & 1 & 1 & 1 & & & & 1 & 1 & & & & & & & 1 & & & 7 \\
\hline $\begin{array}{l}\text { Grand total } \text { captures } \\
\text { Number species detected }\end{array}$ & $\begin{array}{c}92 \\
6\end{array}$ & $\begin{array}{c}77 \\
7\end{array}$ & $\begin{array}{c}203 \\
8\end{array}$ & $\begin{array}{c}106 \\
7\end{array}$ & $\begin{array}{c}66 \\
5\end{array}$ & $\begin{array}{c}69 \\
4\end{array}$ & $\begin{array}{c}51 \\
5\end{array}$ & $\begin{array}{c}35 \\
7\end{array}$ & $\begin{array}{c}90 \\
8\end{array}$ & $\begin{array}{c}31 \\
7\end{array}$ & $\begin{array}{l}49 \\
7\end{array}$ & $\begin{array}{c}31 \\
6\end{array}$ & $\begin{array}{c}109 \\
8\end{array}$ & $\begin{array}{c}144 \\
6\end{array}$ & $\begin{array}{c}94 \\
6\end{array}$ & $\begin{array}{c}81 \\
6\end{array}$ & $\begin{array}{c}67 \\
7\end{array}$ & $\begin{array}{l}3 \\
2\end{array}$ & $\begin{array}{c}1398 \\
11\end{array}$ \\
\hline
\end{tabular}




\begin{tabular}{|c|c|c|c|c|c|c|c|c|c|c|c|c|c|}
\hline \multirow{2}{*}{ 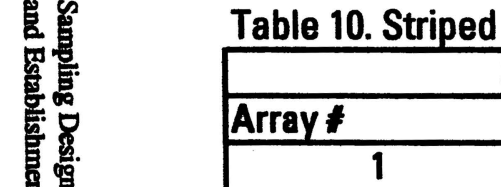 } & \multicolumn{6}{|c|}{ itriped Racer (Adults + Juveniles) } & \multicolumn{7}{|c|}{ Striped Racer (Juveniles Only) } \\
\hline & 1996 & 1997 & 1998 & 1999 & 2000 & Total & Array $\neq$ & 1996 & 1997 & 1998 & 1999 & 2000 & Total \\
\hline 1 & 2 & 1 & & & & 3 & $T$ & 1 & 1 & & & & 2 \\
\hline 2 & & & & & & 0 & 2 & & & & & & 0 \\
\hline 3 & 1 & 1 & & 1 & & 3 & 3 & & 1 & & & & 1 \\
\hline 4 & & & & 1 & & 1 & 4 & & & & & & 0 \\
\hline 5 & & 1 & 1 & 2 & & 4 & 5 & & & & 1 & & 1 \\
\hline 6 & & & & & & 0 & 6 & & & & & & 0 \\
\hline 7 & 2 & & 1 & & & 3 & 7 & & & & & & 0 \\
\hline 8 & 1 & 1 & 1 & & & 3 & 8 & & & & & & 0 \\
\hline 9 & 3 & 1 & 2 & 1 & & 7 & 9 & & & 1 & & & 1 \\
\hline 10 & & 1 & 1 & & 1 & 3 & 10 & & & & & & 0 \\
\hline 11 & & & & & 1 & 1 & 11 & & & & & 1 & 1 \\
\hline 12 & & 1 & & & & 1 & 12 & & & & & & 0 \\
\hline 13 & 1 & 1 & & & 1 & 3 & 13 & 1 & & & & & 1 \\
\hline 14 & 1 & & 1 & & 1. & 3 & 14 & & & & & & 0 \\
\hline 15 & 1 & 1 & & 1 & & 3 & 15 & & & & 1 & & 1 \\
\hline 16 & & & & & & 0 & 16 & & & & & & 0 \\
\hline 17 & & & & 1 & & 1 & 17 & & & & & & 0 \\
\hline Total captures & 12 & 9 & 7 & 7 & 4 & 39 & Total captures & 2 & 2 & 1 & 2 & 1 & 8 \\
\hline$f$ arrays present & 8 & 9 & 6 & 6 & 4 & 14 & $f$ arrays present & 2 & 2 & 1 & 2 & 1 & 7 \\
\hline
\end{tabular}

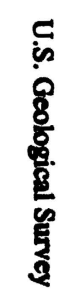


Table 11. Number of captures by sampling period from years 1996-2000. Based upon 50 sample days per year (i.e., 10-day sample periods).

\begin{tabular}{|c|c|c|c|c|c|c|}
\hline Species & Jan/Feb & $\begin{array}{l}\text { Sampling } \\
\text { Apr/May }\end{array}$ & $\begin{array}{l}\text { Period T } \\
\text { June/Ju }\end{array}$ & $\begin{array}{l}\text { ne in Year } \\
\text { Aug/Sep }\end{array}$ & Oct/Nov & Grand Total \\
\hline $\begin{array}{l}\text { Batrachoseps major } \\
\text { Garden slender salamander }\end{array}$ & 72 & 12 & 0 & 0 & 2 & 86 \\
\hline $\begin{array}{l}\text { Anniella pulchra } \\
\text { Silvery legless lizard }\end{array}$ & 1 & 0 & 0 & 0 & 0 & 1 \\
\hline $\begin{array}{l}\text { Cnemidophorus hyperythrus } \\
\text { Orange-throated whiptail }\end{array}$ & 5 & 54 & 180 & 55 & 89 & 383 \\
\hline $\begin{array}{l}\text { Elgaria multicarinatus } \\
\text { Southern alligator lizard }\end{array}$ & 34 & 70 & 20 & 6 & 16 & 146 \\
\hline $\begin{array}{l}\text { Sceloporus occidentalis } \\
\text { Western fence lizard }\end{array}$ & 63 & 133 & 98 & 61 & 69 & 424 \\
\hline $\begin{array}{l}\text { Uta stansburiana } \\
\text { Side-blotched lizard }\end{array}$ & 48 & 56 & 58 & 66 & 67 & 295 \\
\hline $\begin{array}{l}\text { Crotalus viridis } \\
\text { Southern Pacific rattlesnake }\end{array}$ & 0 & 1 & 1 & 2 & 1 & 5 \\
\hline $\begin{array}{r}\text { Diadophis punctatus } \\
\text { Ring-necked snake }\end{array}$ & 1 & 0 & 3 & 1 & 2 & 7 \\
\hline $\begin{array}{l}\text { Lampropeltis getula } \\
\text { California king snake }\end{array}$ & 0 & 1 & 4 & 0 & 0 & 5 \\
\hline $\begin{array}{l}\text { Masticophis lateralis } \\
\text { Striped racer }\end{array}$ & 2 & 11 & 8 & 11 & 7 & 39 \\
\hline $\begin{array}{l}\text { Pituophis melanoleucas } \\
\text { San Diego gopher snake }\end{array}$ & 0 & 1 & 3 & 1 & 2 & 7 \\
\hline Grand total \# captures & 226 & 339 & 375 & 203 & 255 & 1398 \\
\hline \# species detected & 8 & 9 & 9 & 8 & 9 & 11 \\
\hline
\end{tabular}


Table 12. Dependent and independent variables in stepwise regression analysis.

\begin{tabular}{|c|c|c|c|}
\hline \multirow[t]{2}{*}{ Dependent variables } & \multicolumn{3}{|c|}{ Independent variables } \\
\hline & Fauna** & Veqetation & Physifal \\
\hline $\begin{array}{l}\text { \# Snakes } \\
\text { \# Striped racers } \\
\text { \# Lizards and salamanders } \\
\text { \# Orange-throated } \\
\text { whiptails } \\
\text { Argentine ants category }\end{array}$ & $\begin{array}{l}\text { \# Lizards } \\
\text { \# Small mammals }\end{array}$ & $\begin{array}{l}\text { Canopy height } \\
\text { \% Cover } \\
\text { \# Shrub hits } \\
\text { \# Herb Hits } \\
\text { \% Coastal Sage Scrub } \\
\text { \% Chaparral } \\
\text { \% Grass }\end{array}$ & $\begin{array}{l}\text { Elevation (meters) } \\
\text { Slope (degrees) } \\
\text { Cosine aspect } \\
\text { Leaf litter } \\
\text { Sandy soil } \\
\text { Cryptogamic rock } \\
\text { Bare Rock } \\
\text { Cryptogamic soil } \\
\text { Organic soil } \\
\text { Moss }\end{array}$ \\
\hline
\end{tabular}

** Note: Fauna variables only used in analysis for number of snakes captures and number striped racer captures. 
Table 13. Environmental variables stepwise regression results. The results from the stepwise regression analyses to determine what environmental variables were most strongly associated with each dependent variable are summarized below. For a variable to enter or exit the regression model required a probability $>F$ of at least 0.15 . Dependent variables are shown in bold in the table below. The data transformation and the associated $R^{2}$ of the model are also given. Although Argentine ant density category was not included initially in the analysis for number of lizards and salamanders and number orange-throated whiptails, when this variable was added, it became significant in the stepwise regression for these variables and replaced some environmental variables in the resulting equations. Argentine ant density category did not alter the regression equations for number of snakes or number of striped racers.

\begin{tabular}{|c|c|c|}
\hline Parameter Name & Parameter & Probability $>F$ \\
\hline \multicolumn{3}{|c|}{ Results when Argentine ant density category is not allowed as regression variable } \\
\hline $\begin{array}{l}\text { * snakes (transformation }=\operatorname{Ln}(\mathbf{n}+1) ; R^{2}=.53 \text { ) } \\
\text { Intercept } \\
\text { Canopy Height } \\
\text { \% Cover }\end{array}$ & $\begin{array}{r}-0.7768 \\
-0.9385 \\
0.0326 \\
\end{array}$ & $\begin{array}{l}0.2208 \\
0.0782 \\
0.0020\end{array}$ \\
\hline $\begin{array}{l}\text { * striped racers (transformation }=\operatorname{Ln}(\mathbf{n}+1) ; R^{2}=.48 \\
\qquad \begin{array}{l}\text { Intercept } \\
\operatorname{Ln}(\# \text { mammals) } \\
\operatorname{Ln}(\# \text { lizards and salamanders) }\end{array}\end{array}$ & $\begin{array}{r}-6.4391 \\
1.2939 \\
0.6876 \\
\end{array}$ & $\begin{array}{l}0.0335 \\
0.0041 \\
0.0860\end{array}$ \\
\hline $\begin{array}{l}\text { * lizards \& salamanders (transformation }=\operatorname{Ln}(\mathbf{n + 1} \\
\qquad \begin{array}{l}\text { Intercept } \\
\# \text { herbaceous plant hits } \\
\% \text { grasses }\end{array} \\
\end{array}$ & $\begin{array}{r}\text { 0) } \\
4.0046 \\
0.0249 \\
-0.0316 \\
\end{array}$ & $\begin{array}{l}0.0001 \\
0.0028 \\
0.0007 \\
\end{array}$ \\
\hline $\begin{array}{l}\text { * orange-throated whiptails (transformation =Ln } \\
\qquad \begin{array}{l}\text { Intercept } \\
\text { \# Shrub hits } \\
\text { \% coastal sage scrub }\end{array}\end{array}$ & $\begin{array}{l}\left.P^{2}=.46\right) \\
3.5261 \\
-0.0709 \\
0.0807 \\
\end{array}$ & $\begin{array}{l}0.0559 \\
0.0485 \\
0.0057 \\
\end{array}$ \\
\hline $\begin{array}{l}\text { Argentine ants density category (no transformat } \\
\qquad \begin{array}{l}\text { Intercept } \\
\% \text { Coastal sage scrub } \\
\% \text { Grass }\end{array}\end{array}$ & $\begin{array}{l}=.82) \\
1.9316 \\
-0.0104 \\
0.0174\end{array}$ & $\begin{array}{l}0.0001 \\
0.0030 \\
0.0027\end{array}$ \\
\hline Results when Argentine ant density & ory is allowe & ariable \\
\hline $\begin{array}{l}\text { * lizards and salamanders (transformation=Ln(n- } \\
\qquad \begin{array}{l}\text { Intercept } \\
\text { \# Shrub hits } \\
\text { Argentine ant density category }\end{array}\end{array}$ & $\begin{array}{l}63) \\
6.4112 \\
-0.0140 \\
-0.7836 \\
\end{array}$ & $\begin{array}{l}0.0001 \\
0.0082 \\
0.0004 \\
\end{array}$ \\
\hline $\begin{array}{l}\text { \# orange-throated whiptails (transformation =Ln } \\
\qquad \begin{array}{l}\text { Intercept } \\
\text { \# Herb hits } \\
\text { Argentine ant density category }\end{array}\end{array}$ & $\begin{array}{r}\left.P^{2}=.63\right) \\
6.9950 \\
0.0939 \\
-3.7502\end{array}$ & $\begin{array}{l}0.0001 \\
0.0044 \\
0.0008\end{array}$ \\
\hline
\end{tabular}


Table 14. List of species detected since 1995 versus historical records. The coastal rosy boa (Charina trivirgata/ was a single individual found by the roadside and is thought to have been a released pet, since this species is not known historically from the peninsula. The night snake (Hypsiglena torquata) was not known historically in museum records, but a single specimen was documented in 1997 as well as in current surveys. This is a very cryptic, difficult to detect species and could easily have been missed during earlier surveys, and thus is considered to have historically occurred in this area.

\begin{tabular}{|c|c|c|}
\hline 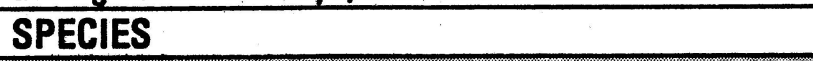 & Current surveys & Historical records \\
\hline 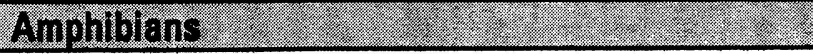 & 2 & 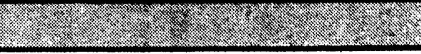 \\
\hline $\begin{array}{l}\text { Batrachoseps major } \\
\text { Garden slender salamander }\end{array}$ & $\mathrm{x}$ & $\bar{x}$ \\
\hline Lizards & 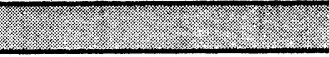 & 20 \\
\hline $\begin{array}{l}\text { Anniella pulchra } \\
\text { Silvery legless lizard }\end{array}$ & $\bar{x}$ & $\bar{x}$ \\
\hline $\begin{array}{l}\text { Cnemidophorus hyperythrus } \\
\text { Orange-throated whiptail }\end{array}$ & $\bar{X}$ & $\bar{x}$ \\
\hline $\begin{array}{l}\text { Eumeces skiltonianus } \\
\text { Coronado skink }\end{array}$ & & $\bar{x}$ \\
\hline $\begin{array}{l}\text { Elgaria multicarinatus } \\
\text { Southern alligator lizard }\end{array}$ & $\bar{x}$ & $\bar{x}$ \\
\hline $\begin{array}{l}\text { Phrynosoma coronatum } \\
\text { Coast horned lizard }\end{array}$ & & $\mathbf{x}$ \\
\hline $\begin{array}{l}\text { Sceloporus occidentalis } \\
\text { Western fence lizard }\end{array}$ & $\bar{x}$ & $\bar{x}$ \\
\hline $\begin{array}{l}\text { Uta stansburiana } \\
\text { Side-blotched lizard }\end{array}$ & $\bar{x}$ & $\bar{x}$ \\
\hline Snakes & 8 & 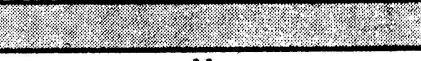 \\
\hline $\begin{array}{l}\text { Arizona elegans } \\
\text { California glossy snake }\end{array}$ & & $x$ \\
\hline $\begin{array}{l}\text { Charina trivirgata } \\
\text { Coastal rosy boa }\end{array}$ & $X$ (introduced) & \\
\hline $\begin{array}{l}\text { Coluber constrictor } \\
\text { Yellow-bellied racer }\end{array}$ & & $\bar{x}$ \\
\hline $\begin{array}{l}\text { Crotalus exsul } \\
\text { Red diamond rattlesnake }\end{array}$ & & $\bar{x}$ \\
\hline $\begin{array}{l}\text { Crotalus viridis } \\
\text { Southern Pacific rattlesnake }\end{array}$ & $\bar{x}$ & $\bar{x}$ \\
\hline $\begin{array}{r}\text { Diadophis punctatus } \\
\text { Ring-necked snake } \\
\end{array}$ & $\bar{x}$ & $x$ \\
\hline $\begin{array}{l}\text { Hypsiglena torquata } \\
\text { Night snake }\end{array}$ & $x$ & $\bar{x}$ \\
\hline $\begin{array}{l}\text { Lampropeltis getula } \\
\text { California king snake }\end{array}$ & $\bar{x}$ & $\bar{x}$ \\
\hline $\begin{array}{l}\text { Masticophis lateralis } \\
\text { Striped racer }\end{array}$ & $\mathbf{X}$ & $\bar{x}$ \\
\hline $\begin{array}{l}\text { Masticophis flagellum } \\
\text { Coachwhip / red racer }\end{array}$ & & $\bar{x}$ \\
\hline $\begin{array}{l}\text { Pituophis melanoleucas } \\
\text { San Diego gopher snake }\end{array}$ & $\bar{x}$ & $\bar{x}$ \\
\hline $\begin{array}{l}\text { Rhinocheilus lecontei } \\
\text { Long-nose snake }\end{array}$ & & $x$ \\
\hline
\end{tabular}


Table 15. Summary table of preliminary control limits for detecting changes from the baseline years 1996-2000. These control limits and data in this table assume that specified data transformations have been conducted, that arrays $\# 6$ and $\# 12$ are discontinued, and that the number of sampling days per year has been reduced from 50 to 40 days, either divided as 58-day sampling periods per year or as 10 4-day sampling periods per year.

\begin{tabular}{|c|c|c|c|c|c|c|c|c|c|c|}
\hline Variable name & Variable & $\begin{array}{c}\text { Transfor } \\
\text { mation }\end{array}$ & $\begin{array}{c}\text { Is Trend } \\
\text { Significant }\end{array}$ & 1996 & 1997 & 1998 & 1999 & 2000 & $\begin{array}{l}\text { Lower } 95 \% \\
\text { Control limit }\end{array}$ & $\begin{array}{l}\text { Lower 99\% } \\
\text { Control limit }\end{array}$ \\
\hline \# Species detected & Average \& species / array / year & $\begin{array}{l}\text { Square } \\
\text { root }\end{array}$ & $\begin{array}{c}\text { Yes } \\
P=.0370\end{array}$ & 1.99 & 1.99 & 2.08 & 1.91 & 1.75 & $\leq 1.70^{*}$ & $\leq 1.62^{*}$ \\
\hline $\begin{array}{l}\text { Relative Species } \\
\text { Evenness }\end{array}$ & Average Evenness / array / year & & No & .75 & .73 & .70 & .73 & .80 & $\leq 0.67 * *$ & $\leq 0.65^{* *}$ \\
\hline Herpetofauna & $\begin{array}{l}\text { Average \# herpetofauna } \\
\text { Captures / array / year }\end{array}$ & $\begin{array}{c}\text { Square } \\
\text { root }\end{array}$ & No & 3.54 & 3.54 & 4.44 & 3.57 & 3.10 & $\leq 2.68 * *$ & $\leq 2.38 * *$ \\
\hline Lizards & Average * lizard captures array / year & $\begin{array}{c}\text { Square } \\
\text { root }\end{array}$ & No & 3.29 & 3.39 & 4.03 & 3.27 & 2.99 & $\leq 2.64^{* *}$ & $\leq 2.41 * *$ \\
\hline Snakes & $\begin{array}{l}\text { Total snake captures / year across all } \\
\text { arrays }\end{array}$ & & No & 9 & 10 & 11 & 11 & 8 & $\leq 4$ & $\leq 3$ \\
\hline & $f$ arrays with snakes present / year & & No & 6 & 8 & 10 & 6 & 5 & $\leq 2$ & $\leq 2$ \\
\hline & Average $\neq$ captures / array / year & $\begin{array}{l}\text { Square } \\
\text { root }\end{array}$ & No & 1.42 & 1.81 & 2.02 & 1.50 & 1.22 & $\leq 0.97^{* *}$ & $\leq 0.77^{* *}$ \\
\hline $\begin{array}{l}\text { Orange-throated } \\
\text { whiptail }\end{array}$ & $\begin{array}{l}\text { f arrays with adults or juveniles } \\
\text { present / year }\end{array}$ & & $\begin{array}{l}\text { Maybe } \\
P=0.0805\end{array}$ & 12 & 11 & 10 & 11 & 9 & $\leq 8$ & $\leq 7$ \\
\hline & $\begin{array}{l}\text { Farrays with juveniles only } \\
\text { present / year }\end{array}$ & & No & 6 & 8 & 9 & 6 & 4 & $\leq 2$ & $\leq 1$ \\
\hline Striped racer & Total captures / year & & $\begin{array}{c}\text { Yes } \\
P=0.0079\end{array}$ & 9 & 8 & 5 & 6 & 4 & $\leq 2^{*}$ & $\leq 1^{*}$ \\
\hline (adults \& juveniles) & $\begin{array}{l}\text { f arrays with adults or juveniles } \\
\text { present/ year }\end{array}$ & & $\begin{array}{c}\text { Yes } \\
P=0.0418 \\
\end{array}$ & 6 & 8 & 5 & 5 & 4 & $\leq 1^{*}$ & $\leq 1^{*}$ \\
\hline $\begin{array}{l}\text { Striped racer } \\
\text { (juveniles only) }\end{array}$ & f consecutive years with zero captures & & & 1 & 2 & 1 & 2 & 1 & \multicolumn{2}{|c|}{$2-3$ years*** } \\
\hline Ring-necked snake & I consecutive years with zero captures & & & 0 & 1 & 2 & 1 & 2 & \multicolumn{2}{|c|}{3 years $* * *$} \\
\hline $\begin{array}{l}\text { Southern Pacific } \\
\text { rattlesnake }\end{array}$ & f consecutive years with zero captures & & & 0 & 0 & 1 & 0 & 3 & \multicolumn{2}{|c|}{$3-5$ years*** } \\
\hline
\end{tabular}

rattlesnake

* If a trend is present then limits are not valid. A test for a trend should be conducted in subsequent (new) years before using control limits.

* A contrast analysis will have greater power to detect a change. However if a variable drops below the given control limit, there will also be a significant difference if a contrast analysis is conducted. Data must be transformed before comparing with control limits (see variable description) 


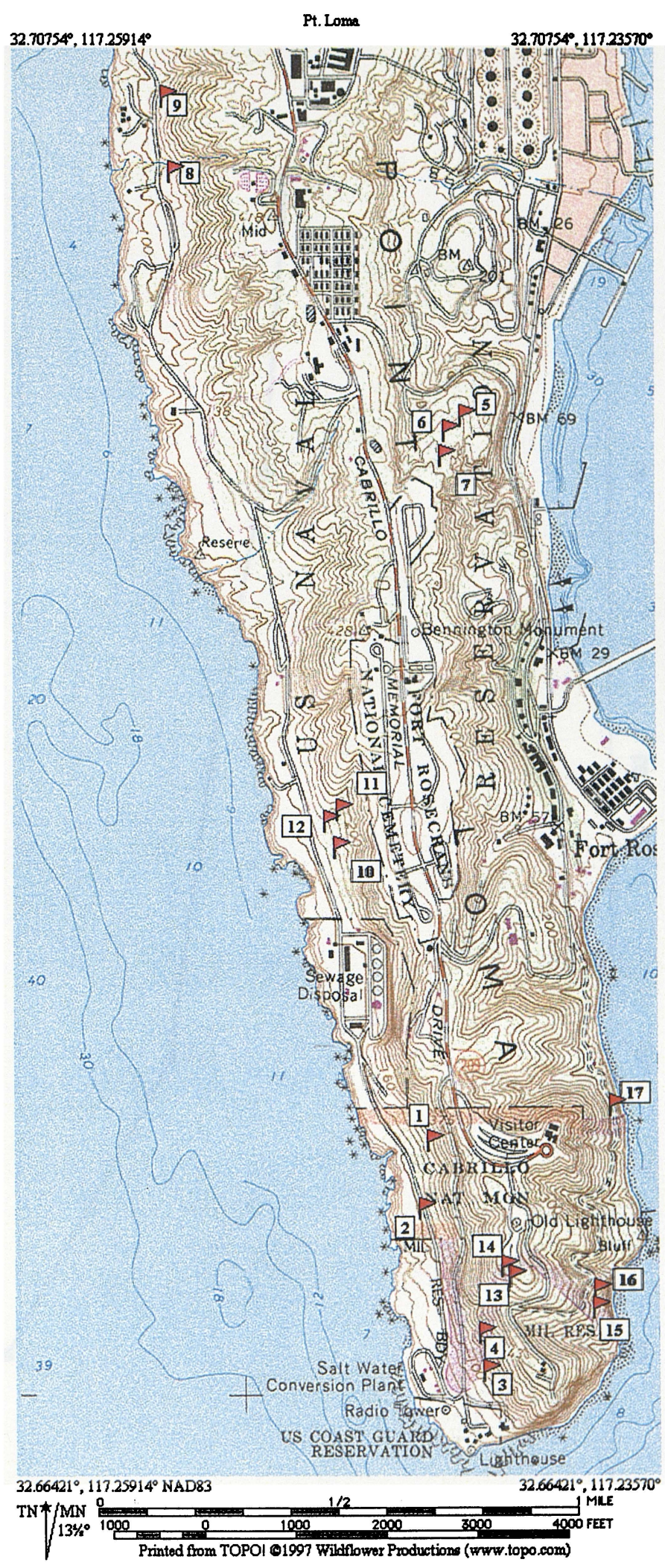

Figure 1. Map of Point Loma Ecological Reserve herpetofauna arrays 


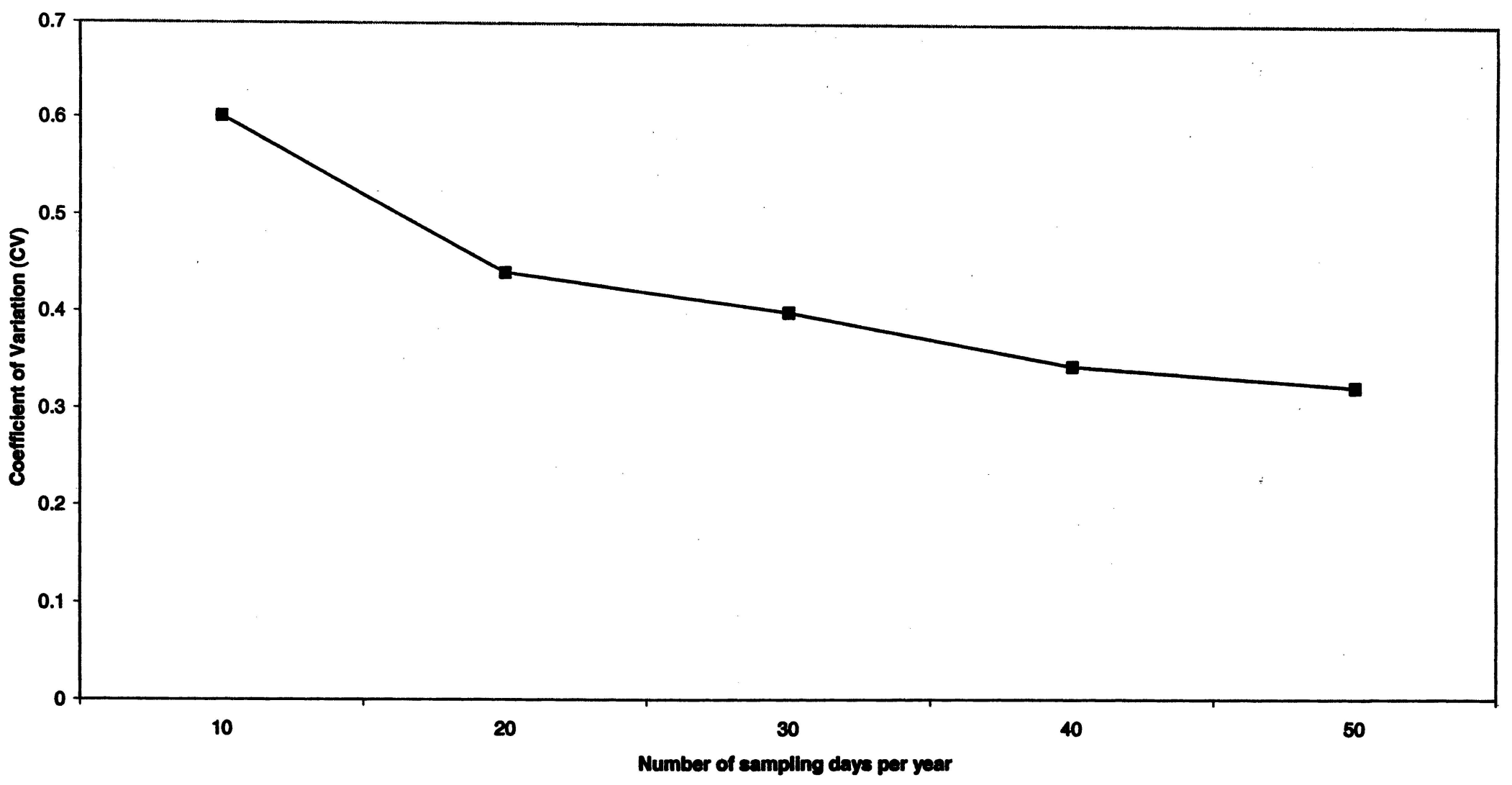

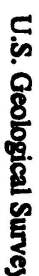

Figure 2. Coefficient of Variation (CV) for orange-throated whiptail capture rates for arrays with $>2$ captures. 


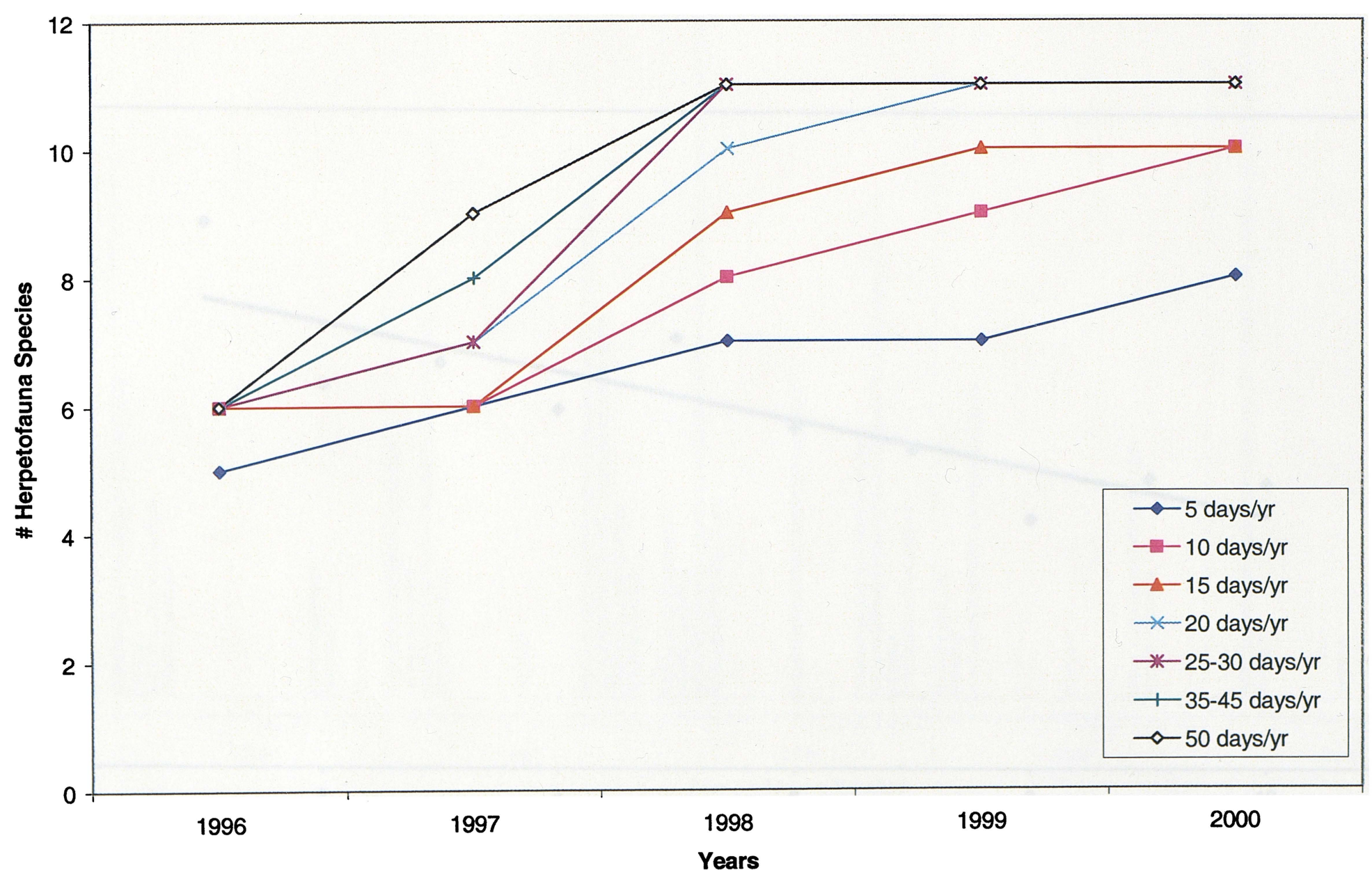

Figure 3. Cumulative number of herpetofauna species detected across all 17 arrays at increasing number of sampling days per year. Please note that night snake (Hypsiglena torquata), the twelfth species, was not captured until 2001. 


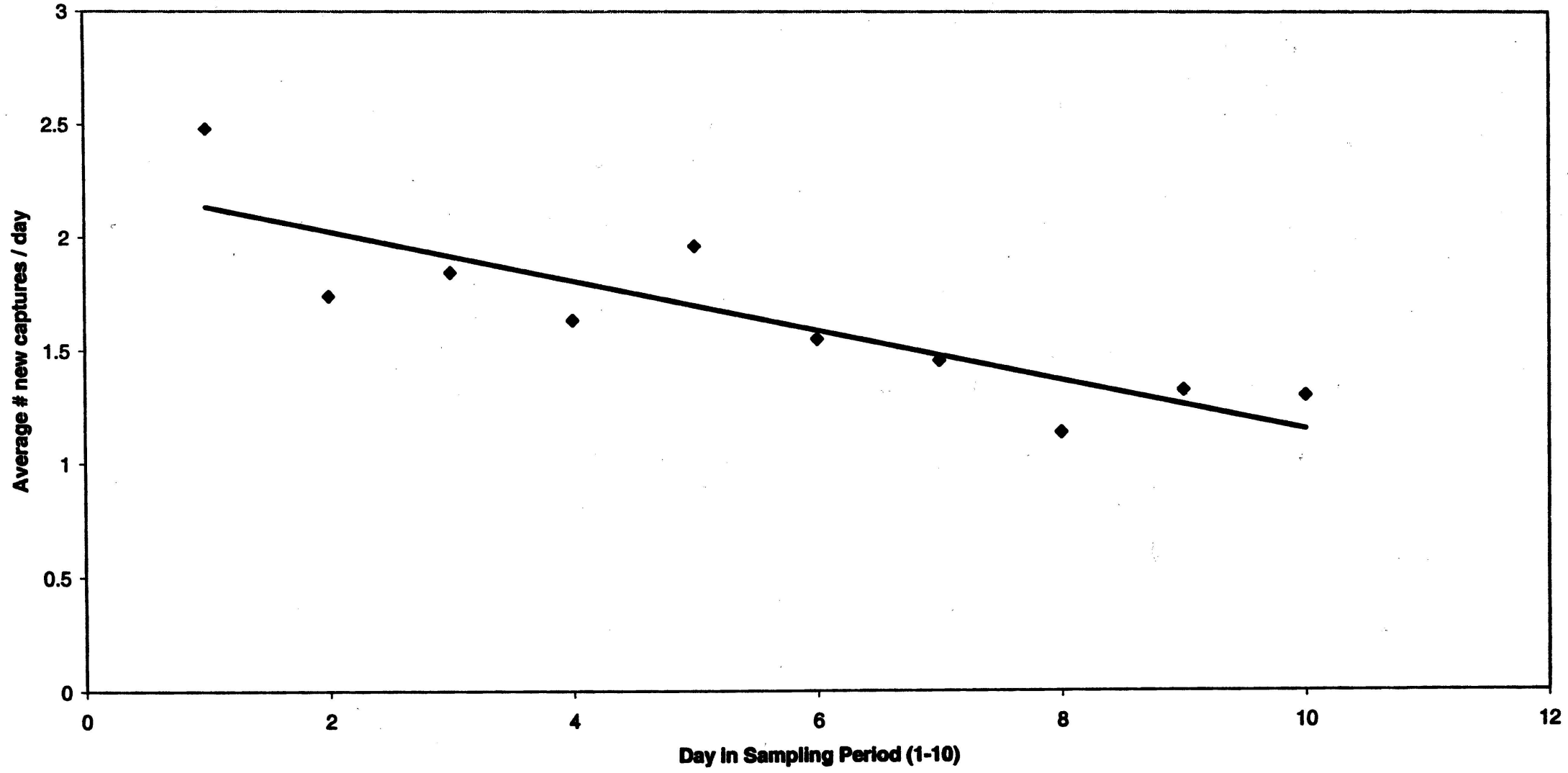

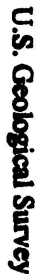

Figure 4. Number of new captures per day by sampling day within the sampling period. Recaptures within same 10-day sampling period were not included. 


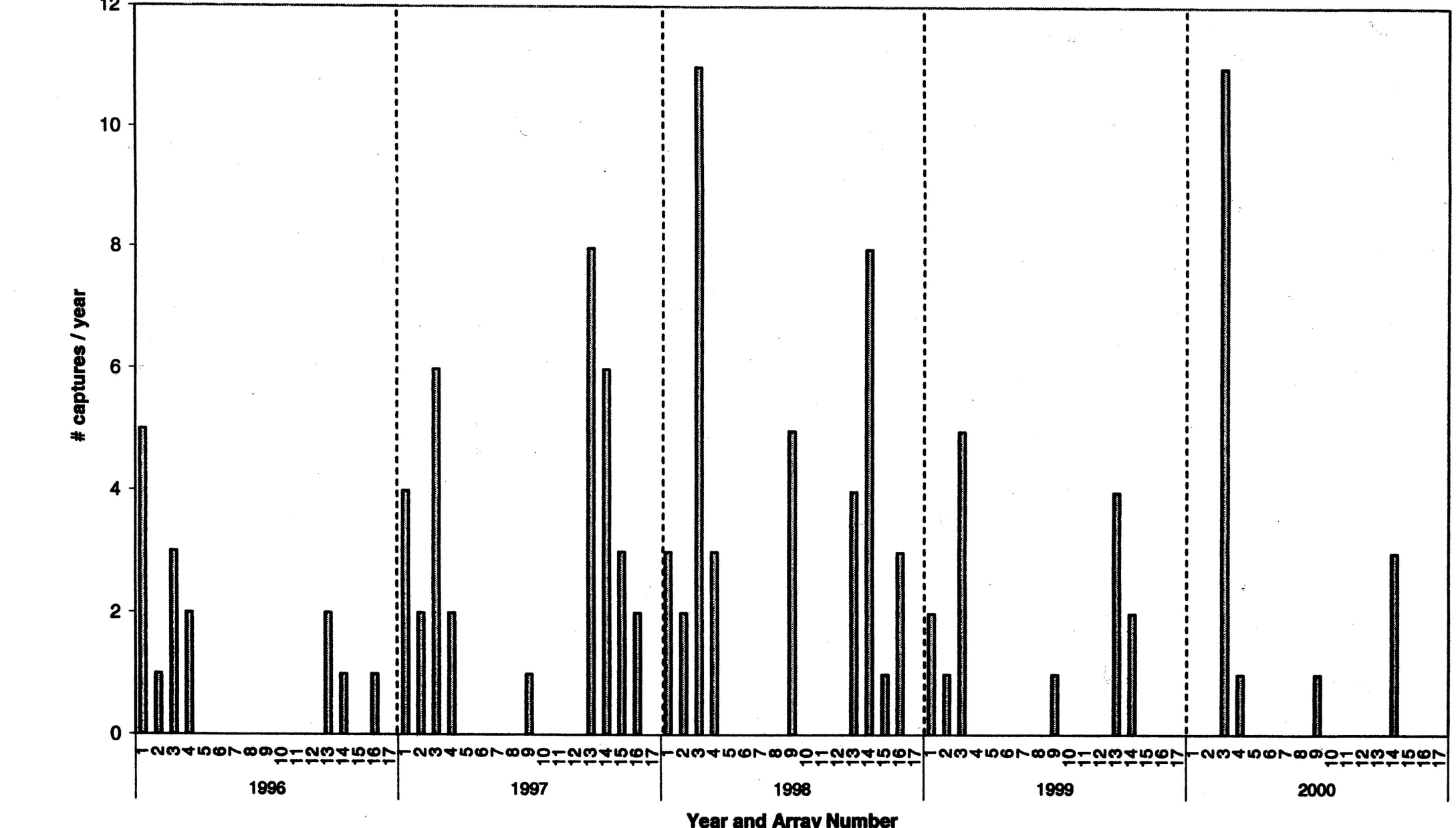



